\title{
The Surprising Reduction of Inequality during a Commodity Boom: What do we Learn from Latin America?
}

\author{
Diego Sánchez-Ancochea \\ University of Oxford \\ Paper accepted in the Journal of Economic Policy Reform \\ 3 June 2019
}

\begin{abstract}
$\underline{\text { Abstract }}$
Past experience and both orthodox and heterodox economic theories lead us to expect a positive relationship between income inequality and commodity booms. Yet Latin America's recent improvement in income distribution coincided with a rapid growth in commodity exports. How was this positive outcome possible? Did income distribution improve because of higher commodity revenues or despite them? This paper answers these questions - seldom explored in the recent literature-using a combination of sources. The paper shows that the reduction of inequality took place among the bottom 90 percent of the population only, while the income share of the wealthy remained stable when properly measured. The reduction in the Gini coefficients had a lot to do with (re) distributive policies that enlarged the impact of labour market outcomes. The paper concludes that political pressures forced most Latin American governments to manage the commodity boom better than in the past in the short run but did not lead to significant transformations in the region's elitedriven development model.
\end{abstract}

Key words: commodity boom, income inequality, labour markets, social policy, Latin America 


\section{Introduction}

By now the reduction of inequality in Latin America during the first decade of the 2000s is well-known (e.g. Clifton et al, 2019; Cornia, 2014; Lustig et al, 2016). At a time when the distribution of income in much of the rest of the world was deteriorating, the Gini coefficient went down in 14 of 18 Latin American countries. Yet what is most surprising and what has been less explored is that this improvement took place in the context of a commodity boom.

Based on theoretical insights and available empirical evidence, we would expect inequality to worsen when income from primary exports increases. Leamer et al (1999), for example, show that Latin America's specialization in natural resources has led to high inequality. Economic historians like Bértola and Ocampo (2012) and Prados de la Escosura (2007) argue that previous commodity booms led to a deterioration in the distribution of income. Across the world, when land and education have been unequally allocated, the gains from higher primary prices have concentrated among small segments of the population (Bhattacharyya and Williamson, 2013). Given all these facts, how was the reduction in the Gini coefficient during the 2000s possible?

One potential answer is that it was just a statistical artefact resulting from the use of household surveys that do not measure income distribution adequately (Székely and Hilgert, 2007). This hypothesis is partly corroborated when using alternative sources of data. In particular, several studies based on tax data and/or national account statistics show that the share of income at the top did not go down in countries like Brazil, Chile and Mexico during this period (Alvarado, 2010; Alvarado and Londoño, 2013; Budin et al, 2014; Morgan, 2017; Fairfield and Jorratt, 2016). And yet there is 
enough evidence to believe that there was some improvement in the overall distribution of income. What were the main determinants of this recent evolution? Did redistribution take place despite the commodity boom or thanks to it?

This paper constitutes one of the first systematic attempts to combine evidence from secondary literature and descriptive statistics to explore these questions. Like Clifton et al (2019) explain in one of the most up-to-date studies on the subject, the recent research on the subject combines single-country studies with either multicountry analyses or cross-country regressions. Although drawing primarily on this second type of evidence, I also use specific country examples when no other data is available.

I make three main points about the relationship between the recent commodity boom and inequality in Latin America. First, the income of the elite (e.g. that of the top 1 percent) remained stable — or may have even increased in some countries. Second, a redistribution of income from the middle class to the poor took place: the share of income received by the bottom deciles (first to third) increased in all countries, while that of the middle and upper middle classes decreased. Third, this overall improvement resulted from the state's growing ability to (re)distribute income towards the poor in the context of democratic pressures and the expansion in the relative demand for unskilled workers. The commodity boom was thus better managed this time than in the past, at least in the short run. Unfortunately, however, these policies did not lead to the erosion of the region's elite-centred model of distribution in the long run.

The paper is divided into five more sections. The first section describes the recent evolution of income distribution and explains why it is surprising in the context of a commodity boom. The second section considers the evolution of income at the 
top, exploring the extent to which it should modify our views regarding recent distributional trends. The third section focuses on the changes in the labour marketincluding growing formalisation and the increase in minimum wages - that are behind the reduction in income inequality. I then review the evolution of tax and social policies, emphasising changes that led to the incorporation of the poor. The paper finishes with some lessons for other parts of the Global South.

\section{The surprising reduction of income inequality in Latin America}

There is a consensus in the literature that income inequality improved in Latin America beginning in the early 2000s. According to estimations by Gasparini et al (2016), the regional Gini coefficient (calculated as the unweighted average of 15 countries) decreased from 0.54 in 2003 to 0.47 in 2012 . The reduction took place across the board: as reflected in Figure 1 income inequality went down in every country but Costa Rica and Honduras.

[Insert figure 1 around here]

This positive trend coincided with a commodity boom (Ocampo and Parra, 2010). Between 2003 and 2013, the prices of oil, mining products and, to a lesser extent, agricultural goods grew rapidly. According to IMF data, the price of energybased commodities multiplied by four, while the price of other commodities doubled. As a result, the terms of trade for commodity exporters increased significantly (ECLAC, 2012 and 2014; Ocampo, 2017). It grew by more than 50 percent in the oil and mining exporting countries: Ecuador, Peru, Colombia, and, especially, Bolivia, Chile and Venezuela. The expansion was also significant in Argentina and Brazil- 
major agricultural exporters - and positive but lower in Mexico, Paraguay and Uruguay. In all these countries, the boom expanded rents in the primary sector and consolidated primary specialization. In contrast, in Central America and the Caribbean — where the Gini coefficient generally decreased less during this periodthe commodity boom had negative consequences in the terms of trade-which decreased between 5 percent in the Dominican Republic and 18 percent in Costa Rica and Honduras — and the balance of payments (Ocampo, 2017).

Many observers have claimed that there is a positive relationship between this expansion of the commodity boom and distributional changes (e.g. World Bank, 2015). Yet the reduction in income inequality is surprising precisely because it took place in the context of a commodity boom. When the concentration of land and human capital is unequal, the expansion of oil, mining and agricultural products has usually resulted in regressive income changes. This is evident, for example, in the first wave of globalisation in the late $19^{\text {th }}$ century when, according to Williamson (2009: 22), "Latin America faced a rising terms of trade... as commodity prices boomed...Land and mineral rents were driven up relative to wages....Since land and mineral resources were held by those at the top, inequality rose as well" (Williamson, 2009: 22). Prados de la Escosura (2007) offers concrete evidence of this negative relationship between commodities and distribution during the first globalisation. He compares GDP per worker with real wages for unskilled workers in Argentina, Brazil, Chile, Colombia, Mexico, and Uruguay. This ratio increased significantly during the last decades of the $19^{\text {th }}$ century, demonstrating a deterioration in the relative position of low-income groups.

Econometric work from other parts of the world corroborates this negative relationship between commodity prices and inequality. For example, Bhattacharyya 
and Williamson (2013) explore the impact of mining and wool prices on the share of income of the top 1 percent in Australia for the period 1865-2007. Using an autoregressive conditional heteroskedastic $(\mathrm{GARCH})$ time series model and relying on tax data, they found that a one percentage point increase in the growth rate of commodity prices increases the top 1 percent share of income by 0.35 percentage points - a significant amount in statistical and economic terms. The negative effect of prices on distribution disappeared in the long run in the case of wood, but not in the case of mining.

These empirical results are also consistent with expectations from most mainstream trade models. Mining and agriculture are intense in the use of land, capital and skilled labour and they tend to create limited number of unskilled jobs. In contexts of high concentration of land and mining ownership and unequal access to education and capital, an expansion of these sectors will benefit the wealthy and the professional class.

Structuralist economists have shared their concern about the impact of natural resources on income distribution (Cimoli and Rovira, 2008). According to Fajnzylber (1990: 78), "the supply of natural resources, which in many countries is concentrated in a small proportion of the population or centralized in public enterprise, often has a negative influence on the income- distribution process". This problem results from economic factors and from the impact of rent concentration in politics (Prebisch, 1976).

The recent trend is also surprising when compared to previous decades. During the last 1980s and 1990s, inequality worsened in most Latin American countries: the (unweighted) Gini coefficient increased by close to two percentage points with a particularly rapid growth in the Andes (Gasparini et al, 2011). 
According to most authors, the combination of trade liberalisation-which continued in the 2000s — and skilled-biased technological change was behind this negative trend (Cornia, 2014), which then shifted after 2002-03.

Given all this theoretical and empirical evidence, how can we explain the recent reduction of the Gini coefficient? Did it actually happen? And if it did, what was its connection to the commodity boom? I will answer these questions in turn in the following sections.

\section{Did inequality really decrease?}

To answer this first question requires paying close attention to the evolution of top incomes. According to household surveys, the income share of the top 10 percent decreased in all countries (Figure 2), but there are reasons to be doubtful. There is ample evidence that much of the income of wealthy individuals remains unreported: the very rich are seldom included in the surveys and those interviewed are not forthcoming about their financial position. For example, the average annual income of the two richest households in 2006 according to household surveys was US\$168,000 in Argentina, US\$210,000 in Peru and US\$516,000 in Mexico-well below what one can expect based on regional wealth estimations (Lustig, 2012).

[Insert figure 2 around here]

A number of studies have recently calculated the income shares for the richest 1 percent of the population through alternative methods. Five of these studies rely exclusively on income tax data and apply the methodology developed by Atkinson, Piketty and Saenz (Table 1). One of the two studies on Brazil and Chile combine 
income tax receipts and national account statistics. The Mexican case relies exclusively on adjustments of the household surveys based on information from the national account statistics — a methodology first proposed by Lakner and Milanovic (2013).

The findings from these studies are striking. First, the share of the top income in Latin America is comparatively high. Second, these shares are several points higher than the estimates based on household surveys. For example, in the case of Brazil, the income share of the top 1percent is twice as large when using a combination of fiscal and national accounts sources than when using household surveys (Morgan, 2017). Third, there are large disparities in income concentration within Latin America. Although these differences partly result from the type of information included (particularly how capital gains are measured), they also reflect power asymmetries. Not surprisingly, the share is lower in Argentina and Uruguay than in Brazil, Chile, Colombia and Mexico.

[Insert table 1 around here]

Fourth and more significant for this paper, the income in the hands of the top one percent has remained stable in recent years. The two exceptions are Chile and Mexico where the income share actually increased by several percentage points between 2003 and 2013.

The evidence on top income forces us to temper our initial claim: income distribution probably improved less than initially expected. Nevertheless, it did improve. For example, in Uruguay, the Gini coefficient based on tax data also decreased, even if less than the one based on household surveys. In Colombia, 
Alvaredo and Londoño (2013) calculate a corrected Gini coefficient using the distribution from tax data for the top 1 percent and the distribution from household surveys for the rest. This Gini coefficient decreased from 61.2 in 2007 to 57.5 in 2009, increasing just slightly to 58.7 in 2010. In the case of Brazil, Morgan (2017: 15) recognizes that "inequality among the bottom $90 \%$ declined."

A comparison of the evolution of all decile in every Latin America based on household surveys corroborates the positive trend just mentioned (see appendix A). In most countries, this curve decreases monotonically. The only exceptions are Colombia (where the upper middle class did particularly well), Costa Rica (where the share of the ninth decile grew more than that of the middle classes) and Honduras (where the top decile was the only one improving its share). Even in those three cases the poorest 20 percent benefited more than the rest. As a result, we can comfortably assume that a redistribution of income from the upper middle class and the middle classes to the poor took place in Latin America during the 2000s.

\section{Changes in the labour market}

As an average, changes in labour income explain almost two thirds of the improvement in income distribution during the 2000s (Lustig et al, 2016). This average hides some significant country differences. In Argentina, for example, labour income was responsible for three quarters of the drop, compared to just half in Brazil (Alejo et al, 2014; Barros et al, 2010). In all countries, the skill premium - that is, the gap between the wages received by skilled and unskilled workers-was behind labour's positive contribution. Between 2003 and 2013, wages for unskilled workers grew more than 4 percent per year compared to less than 2 percent for skilled workers (World Bank, 2015). 
A number of influential authors have claimed that the expansion in education was behind this change in the skill premium. According to López Calva and Lustig (2010: 5), for example, "the decrease in the earnings gap... seems to be mainly the result of the expansion of basic education during the last couple of decades" (italics added). According to their data, the distribution of years of education improved significantly in this period: the Gini coefficient for years of schooling among the adult population decreased by 5 percentage points in Brazil between 1998 and 2007, by 7 percentage points in Mexico between 1996 and 2006 and by 4 percentage points in Peru between 2001 and 2007. Using cross-country regression analysis, Cornia (2010) and Clifford et al (2019) also highlight the positive contribution of public spending in education.

Yet, while education contributed to reduction in the wage gap, it was not the main factor. Figure 3 compares the growth in the years of education of the labour force in the 1990s and the 2000s. In most Latin American countries, the average years of education of the labour force increased more in the 1990s when inequality was actually growing.

[Insert figure 3 around here]

Gasparini et al (2011) identify other factors to account for the narrowing skill premium. Using data for 16 Latin American countries for the period 1989-2009, they estimate the skill premium and the relative supply of workers at different education levels. One exercise compares those with some tertiary education with those with a high school diploma or less, while the other considers the gap between those with high school diploma and those with less than secondary school. Gasparini et al (2011) 
then determine the demand for labour as a residual. Their study reaches several conclusions. First, the relative supply of skilled workers expanded continuously and at a constant pace during the whole period. Second, the trajectory of the wage premium had a concave shape: it increased in all countries (except Brazil) during the 1990s and decreased everywhere during the 2000 s. In some cases, this reduction was large enough to offset the previous expansion, leaving the skill premium at a lower level. Third, changes in the relative demand for skilled labour thus played a central role in explaining wage inequality: with a few exceptions, it increased rapidly in the 1990s, but then went down unexpectedly in the 2000s.

We know why the relative demand for skilled workers and the skill premium increased during the 1990s (Cornia, 2014). Trade liberalization forced companies to respond to external competition. Many reduced the number of workers they hired and adopted skill-biased technical change. At the same time, the privatization of public companied also affected the overall level of employment, hitting unskilled workers particularly hard. Why did these tendencies reverse in the 2000s?

One hypothesis has to do with the impact of the commodity boom on employment and production at the sectoral level. The increase in the price and quantity of commodities demanded often leads to a Dutch disease: an appreciation of the exchange rate and thus a reallocation of resources away from uncompetitive manufactures (Bacha and Fishlow, 2011). An overvalued exchange rate together with higher economic growth is also likely to increase the demand for non-tradable services such as trading and construction, which tend to be intensive in unskilled labour (Corden, 1984; Goderis and Malone, 2011).

The service sector did expand across the region during this period (Weller, 2014). Figure 4 compares its share in total employment in 2002 and 2013: for the 
region as a whole, it increased by three percentage points while the manufacturing sector continued shrinking. The trend was present in all countries and was particularly large in Bolivia and Peru.

[Insert figure 4 around here]

Yet more disaggregated data questions the role of structural change in the reduction of the skill premium. According to the World Bank, for example, "sector shift and job-quality improvement have been small across LAC [Latin America and the Caribbean], suggesting that they explain little of the wage growth experienced by unskilled and low-skilled workers since 2003" (World Bank, 2015: 31).

Gasparini et al (2011) explore the impact of within-sector and between-sector changes in employment on the demand for skills. To do so, they consider nine different productive sectors (primary, three sub-groups within manufacturing and five sub-groups within services) and compare their evolution in the 1990s and 2000s. Between-sector changes take place when there is a transfer of jobs from low-skill- to high-skill-intensive sectors. Within sector changes occur when there are relative changes in demand in each of the nine sectors.

During the 2000s, almost all the relative changes in tertiary employment in Argentina, Mexico, Nicaragua, Paraguay and Venezuela resulted from changes within sectors. In Brazil, Chile, Costa Rica and El Salvador, the contribution of betweensector changes was positive but accounted for less than 30 percent of the total.

What explains the reduction in the skill premium then? Economic growth together with the expansion of minimum wages were probably the primary drivers. Higher economic activity contributed to job creation: between 2001-03 and 2011-13, 
the unemployment rate decreased in 13 of the 17 countries (Figure 5). The only four countries where it remained stable or increased were non-commodity exporters. More significantly, the unemployment rate for those with primary education or less experienced an even higher reduction than the average in most cases.

[Insert figure 5 around here]

The contrast between commodity exporters (for the World Bank, Chile, Bolivia, Colombia, Peru, Ecuador, Brazil and Argentina) and non-commodity exporters (Dominican Republic, Guatemala, Honduras, Mexico, Paraguay, El Salvador, and Uruguay) is also evident when considering the evolution of wages between 2003 and 2013. In the former, wages of unskilled workers increased more than 5 percent per year in both tradable and non-tradable sectors-compared to 1 to 3 percent for skilled workers. In contrast, wages in non-commodity exporting countries remained stagnant or decreased for all groups (World Bank, 2015: 33).

The drop in the unemployment rate coincided with a reduction in the informal sector (Sojo, 2017). The share of informal jobs in the total decreased from 61 percent in 2000 to 51 percent in 2010. Formalization was particularly intense among lowincome workers: according to a recent World Bank-sponsored study, between 2002 and 2013, formal employment in Argentina grew exclusively among workers in the bottom 25 percent of the wage distribution; in Bolivia among those in the bottom 50 percent and in Brazil among those in the bottom 75 percent (Messina and Silva, 2018).

The expansion of the formal sector was partly driven by state intervention. Across the region, governments begun paying more attention to regulation, increasing 
the budget for labour inspections (Berg, 2011; Murillo et al, 2011; Ronconi, 2012). According to Weller (2014: 25 and 26), "many countries modified their approach to labour institutions (...) Given disparities in legislation and compliance, several countries increased the amount of resources for labor inspection... Moreover, many countries developed schemes to promote labour and business formalization, primarily among small and micro-enterprises." In Brazil, for example, several laws simplified the process of registration and tax payments for this kind of companies, while new incentives for the formalization of domestic workers were introduced (Berg, 2011). Argentina (as well as other countries like Uruguay) adopted special social security regimes for domestic workers, as well as new tax incentives to promote formalization (Maurizio, 2014). In the Southern Cone, there were also renewed efforts to strengthen trade unions, collective bargaining and job training (Weller and Roethlisberger, 2011).

In several countries the management of the minimum wage was also a significant factor. As reflected in Figure 6, the growth of the minimum wage was particularly impressive in Brazil, Honduras, Nicaragua and Uruguay.

\section{[Insert figure 6 around here]}

Maurizio and Vázquez (2016) evaluate the impact of the minimum wage on wage distribution in four countries. Based on household surveys and a semiparametric technique, they estimate counterfactual density functions to see what would have happened with a stagnant minimum wage. They find a significant positive effect in Argentina, Brazil and Uruguay as a result of wage compression at the bottom of the distribution. The growth of the minimum wage was responsible for an 
estimated 86 percent of the reduction in the Gini coefficient for wages in Brazil, 27 percent in Argentina and 12 percent in Uruguay. In contrast, the impact of the minimum wage in Chile was not significant—not surprisingly given its lower growth (Keifman and Maurizio, 2012; Moreno Brid et al, 2016).

The usefulness of the minimum wage as a tool to promote equality partly depends on how many workers it benefits. In countries with high informal sectors, the impact will be minimal (Messina and Silva, 2018). This was indeed the case in Honduras where the minimum wage was very high, yet 32 percent of workers earned less than 90 percent the minimum wage (World Bank, 2015). Policy design also matters: in countries like Mexico and the Dominican Republic, there are multiple minimum wages depending on the type of firm and economic sector (World Bank, 2015). This creates inequalities among low-income groups and reduces the overall impact of any expansion in the minimum wage.

In summary, by contributing to economic growth and employment creation, this commodity boom probably had a more positive effect on income distribution than previous ones. More significantly, the boom was better managed: in several countries, governments promoted labour market formalization and significant increases in the minimum wage, leading to overall wage compression. While labour market indicators were also positive in non-commodity exporters, improvements were less significant.

\section{Tax and social policies and the incorporation of the poor}

Although changes in the labour markets drove the reduction of inequality, redistribution through taxes and public social spending was also important. Governments succeeded in expanding their revenue capacity. For the region as a whole — including the Caribbean — total taxes as percentage of GDP increased by 4.3 
percentage points between 2000 and 2013 compared to an increase of 2.6 percentage points during the 1990s (OECD et al, 2016).

As reflected in Figure 7, the improvement in performance happened in most of Latin America. In eleven of the countries, the expansion was more significant in the second period than in the first, in two it was the same and in five it was lower. Most commodity exporters including Venezuela, Argentina, Bolivia, Ecuador Peru and Venezuela were among the most successful cases in the 2000s.

[Insert figure 7 around here]

Even more significant than the expansion of total revenues was the change in the tax structure. Table 2 measures the degree of progressivity (i.e. the ratio between income and consumption taxes) for 1990, 2000 and 2013. This indicator grew faster during the 2000s in every country for which data is available with the exception of Argentina and Panama. For Latin America as a whole, the degree of progressivity expanded by ten percentage points between 2000 and 2013, compared to a reduction from 122 percent in 1990 to 78 percent in 2000.

[Insert table 2 around here]

The significance of this shift for the reduction of inequality cannot be overstated. Historically, Latin American countries developed regressive tax systems that benefited the economic elite (Clifton et al, 2016). As a result, and in contrast to OECD countries, the distribution of income after taxes was often more unequal than before (Goñi et al, 2008; Mahon, forthcoming). This has changed recently: according 
to calculations from Cornia et al (2011), between the 1990s and the 2000s the redistributive capacity of taxation changed from negative to positive in nine countries and it became less negative in two. In their cross-country econometric study of the role of fiscal policy on income inequality, Clifton et al (2019) show that personal income taxes had a statistically significant and positive effect on inequality in the period 2003-2014 but no impact between 1990 and 2002. They find that one percentage point increase in the share of personal income taxes on GDP led to a reduction between 0.005 and 0.007 in the Gini coefficient.

Some authors have linked this change in Latin America's tax structure to progressive reforms resulting from democratic pressures (Cornia et al, 2014). For example, Bird and Zolt (2015) talk about a process of "tax contracting" which reflects "a marked increase in democracy in the region... a substantial expansion of the middle class... and the emergence of an increasing number of left-of-center governments" (p. 323).

Yet there is little doubt that the commodity boom was also important (CAF, 2013). As figure 8 shows, in commodity exporting countries, the share of public revenues from hydrocarbons in GDP went from less than 4.4 percent in 2001 to 6.7 percent in 2012. As a result, its share in total revenues increased by five percentage points. The positive contribution from commodities was particularly high in Bolivia (where it increased by almost six percentage points) and Ecuador (four percentage points), but all primary exporters benefited (Cornia et al, 2014).

[Insert figure 8 around here] 
Higher tax revenues allowed Latin American countries to increase social spending significantly (Mahon, forthcoming). In per capita basis, social spending by the central government increased by almost 50 percent, going from 671 constant dollars in 2002 to 997 in 2013 (Figure 9). The commodity-rich Andean countries performed even better: per capita spending by the general government expanded by 167 percent in Ecuador, 91 percent in Peru and 81 percent in Bolivia according to ECLAC data.

[Insert figure 9 around here]

Figure 10 shows the changes in public spending as percentage of GDP in the main social sectors: education, health, housing and social protection (including noncontributory transfers). While all of them performed well during this period, the expansion was particularly significant in the case of social protection. As discussed below, this was the result of new social policy innovations like conditional cash transfers (CCTs).

[Insert figure 10 around here]

Of course, more social spending does not always translate into more redistribution. In Latin America, many social programs like pensions traditionally targeted the middle class and the wealthy alone, making income distribution even more unequal (Goñi et al, 2008; Lustig et al, 2012). Yet this expansionary phase was different, benefiting the poor more than other income groups (Antía, 2018; Martínez Franzoni and Sánchez-Ancochea, 2014). Most commodity exporters like Argentina, 
Bolivia, Chile or Ecuador introduced radical and/or social democratic policies - to use Reygadas and Filgueira (2010)'s terminology—-that went well beyond the antipoverty programs of the 1990 s.

The positive impact of social policy on low-income groups was evident in three different areas. First, almost all Latin American countries implemented CCTs. Initially launched in Brazil and Mexico in the late 1990s, CCTs provide a small income to poor families who meet certain conditions (or co-responsibilities) such as taking their children to school or to health check-ups. By 2013, 129 million poor people - one in four Latin Americans - were beneficiaries of such a transfer (World Bank, 2013). Some of the largest programs were in commodity exporting countries, including Bono de Desarrollo Humano in Ecuador and Bolsa Familia in Brazil (Johannsen et al, 2009).

While there is much debate about the usefulness and impact of CCTs, most observers agree that they contributed to the reduction of poverty and inequality. For example, Stampini and Tornarolli (2012) argue that the poverty headcount index in Latin America would have been 13 percent higher without the implementation of CCTs and conclude that the programs "proved to be effective at reducing poverty and inequality" (p. 3).

The second positive social policy innovation was the creation and/or expansion of programs funded with general taxes in other areas. In the case of health care, Latin American countries followed two different routes (Martínez Franzoni and Sánchez-Ancochea, 2016). Brazil, Chile and Uruguay introduced reforms that expanded the public system, linking it to the previous social insurance architecture. The reformed systems reduced gaps between different sub-programs and improved both the access and quality of health services. Other countries like Mexico and Peru 
created targeted, non-contributory programs for the poor. Although less universal, this second route also enhanced the redistributive capacity of social interventions.

In the case of pensions, five countries (Argentina, Chile, Uruguay, Brazil and Costa Rica) reformed their contributory systems, while nine (Argentina, Bolivia, Brazil, Chile, Costa Rica, Ecuador, El Salvador, Mexico and Uruguay) either created or expanded non-contributory programs for the poor (Martínez Franzoni and SánchezAncochea, 2016). In terms of redistribution, non-contributory programs were particularly important, especially in those countries with high levels of informality. Undoubtedly Bolivia, where Renta Dignidad was extended to the whole population above 60 years of age in 2008, was the most significant case (Vargas and Garriga, 2015).

The last change had to do with the growth in the number of workers with access to social insurance. As reflected on Table 2, the share of the working population with access to either health or pension insurance increased by nine percentage points between 2000 and 2012 . The expansion was particularly large among workers in small firms - a majority in Latin America—where the share of insured workers went from 33 percent to 50 percent.

[Insert table 3 around here]

The combination of new (contributory and non-contributory) social policy interventions and the labour market formalization efforts discussed in the previous section expanded access to social rights and reduced coverage gaps between different groups. Commodity exporters benefited more than non-commodity exporters. For example, in the case of health care (see Table 3), between 2000 and 2013, health 
insurance coverage increased by 17 percentage points for salaried workers and 26 percentage points for non-salaried workers in commodity exporters, but by only 3.4 and 3.5 percentage points in non-commodity exporters. The performance in Colombia, Mexico and Peru was particularly positive. The reduction of the gap between low and high-income workers and between domestic workers and public sector employees - two groups at the two extremes of the insurance distribution-was also much higher in those Latin American countries that benefited from the commodity boom.

[Insert table 4 around here]

Despite these positive trends during the 2000 s, the redistributive capacity of the public sector is still insufficient (Levy and Shady, 2013). Tax systems remain more regressive than in OECD countries: in 2013 the degree of progressivity was 88 percent in Latin America compared to 178 percent in the OECD and the tax burden lower. Contributory pensions and tertiary education, which represent a significant share of total spending, are regressive in most — although not all—countries (Lustig, 2017). CCT and other non-contributory programs are small and do not generally cover basic needs. Additionally, segmentation - that is, differences in the quality and sufficiency of benefits among Latin Americans - is a major problem caused in part by differences between contributory and non-contributory interventions (Martínez Franzoni and Sánchez-Ancochea, 2018). Unfortunately, all these problems have worsened in recent years after the end of the commodity boom. 


\section{Conclusions}

Commodity booms more often than not result in a worsening of the distribution of income. They have traditionally benefited landowners as well as the elite who controls mining and hydrocarbons and skilled worker working in these sectors. In many Latin American countries, states have historically been unwilling or unable to redistribute income from the boom to low income groups.

Some of these distributional problems are also evident in Latin America's most recent commodity boom during the early 2000s. The participation of wealthy individuals in national income has not decreased — at least when measured with tax data and/or national accounts statistics. Although more studies for more countries are required, the position of top income groups seems to be as strong as ever across Latin America.

Nevertheless, overall income distribution did improve in Latin America thanks to a significant redistribution from the upper middle class to other groups. How was that possible? Why did the region perform better this time than in the past? What can other developing countries learn from this experience? Despite abundant research explaining the recent reduction of inequality in Latin America, few have tackled these questions directly.

This paper has shown that the commodity boom contributed to the reduction in the Gini coefficient through several channels. Some of them were driven by market forces. For example, higher economic activity contributed to lower unemployment and led to the expansion of formal jobs - particularly among unskilled workers. As a result, the skill premium decreased despite the lack of significant structural change.

Yet the paper has demonstrated that public policy was also fundamental: states managed the commodity boom more effectively than in previous episodes — at least in 
the short run. Governments across the region promoted labour market formalization and improvements in the minimum wage. They introduced measures to control a higher share of commodity rents than in the past as well as social policy innovations. The creation of non-contributory programs for the poor was particularly important.

Why did Latin American states behave differently now? Although providing a full answer to this question is beyond the scope of this paper, we should mention three different factors. The consolidation of democracy forced governments of all ideological persuasions to pay more attention to redistribution, poverty reduction and social incorporation (Bird and Zolt, 2015; Huber et al, 2008). Electoral competition (together with the poor economic performance of the 1990s) led to the 'Pink Tide'. Leftist governments won presidential elections in most countries during the early 2000s, reshaping regional policy debates and influencing more conservative governments in Colombia or Mexico (Huber and Stephens, 2012). International forces also made a positive contribution: higher economic growth and more democratic pressures coincided with a growing global attention to inequality and a renewed call for more universal social policies. All these factors were also important for noncommodity exporters, which also witnessed a reduction of inequality. Nevertheless, since these countries faced more complicated economic conditions, it is not surprising that their Gini coefficient experienced a lower reduction and that policy change was less significant.

The Latin American experience thus confirms the central role of politics in the management of the commodity boom. Even in weak institutional environments, electoral competition can make a difference in the short run. By exerting distributional pressures and giving some voice to the poor, democracy can lead to more redistribution in good times. 
Yet Latin America also demonstrates the limits of low-quality democracies and weak institutions. While most governments succeeded in redistributing commodity rents, few adopted the kinds of political and economic reforms required to sustain distributional gains over the long run. Taxes remained insufficient and/or regressive, dynamic structural change was absent (in fact, deindustrialization was a problem in several countries) and the elite is as powerful as ever. In this way, the reduction of inequality during the 2000 s may have been a mirage and not the historical transformation that many were hoping to achieve. 


\section{Acknowledgements}

An earlier version of this paper was prepared for a keynote at the XVII Conference of International Economics in La Coruña (Spain). I thank María Carmen Díaz Roldan for her invitation and to all participants for their comments. I am also thankful to participants in seminars at the Universidad del Pacífico in Lima (Peru), the Universidad Católica de Antofagasta (Chile) and the Universidad Tecnológica del Norte in Cartagena (Colombia). I also acknowledge the useful comments of two anonymous referees.

\section{References}

Alejo, J., M. Bergolo and F. Carbajal. 2014. "Las transferencias públicas y su efecto distributivo. La experiencia de los países del Cono Sur en el decenio de los 2000." El Trimestre Económico, 81(321): 163-198.

Alvarado, F. 2010. "The Rich in Argentina over the Twentieth Century, 1932-2004." Top Incomes: A Global Perspective edited by in Atkinson, A. and T. Piketty. Oxford: Oxford University Press, pp. 253-298.

Alvarado,F. and J. Londoño. 2013. "High Incomes and Personal Taxation in a Developing Economy: Colombia, 1993-2010." Commitment to Equity Working Paper No 12.

Antía, F. 2018. "Regímenes de política social en América Latina: una revisión crítica de la literatura." Desafios, 30(2): 193-235.

Atria, J., I. Flores, C. Sanhueza and R. Mayer. 2018. "Top Incomes in Chile: A Historical Perspective of Income Inequality (1964-2015). WID Working Paper Series no 2018/11.

Bacha, E. and A. Fishlow. 2011. "The Recent Commodity Price Boom and Latin American Growth: More than New Bottles for an Old Wine?" In The Oxford Handbook of Latin American Economics edited by Ocampo, J.A. and J. Ros. Oxford: Oxford University Press.

Barros, R., M. de Carvalho, S. Franco, and R. Mendonça. 2010. "Markets, the State, and the Dynamics of Inequality in Brazil" in López Calva, L. and N. Lustig (eds).

Berg J. 2011. "Laws or Luck? Understanding Rising Formality in Brazil in the 2000s." In Regulating for Decent Work. Advances in Labour Studies edited by Lee S. and D. McCann. London: Palgrave Macmillan.

Bértola, L. and J.A. Ocampo. 2012. The Economic Development of Latin America since Independence. Oxford: Oxford University Press.

Bhattacharyya, S. and J. Williamson. 2013. "Distributional Impact of Commodity Price Shocks: Australia over a Century." CSAE Working Paper 2013-11.

Bird, R. and E. Zolt. 2015. "Fiscal Contracting in Latin America." World Development, 67: 323-335. 
Burdín, G., F. Esponda and A. Vigorito. 2014. "Inequality and Top Incomes in Uruguay: a Comparison between Household Surveys and Income Tax Micro-data." The World Top Incomes Database Working Paper 2014/1.

CAF. 2013. RED 2012: Public Finance for Development. Strengthening the Connection between Income and Expenditure. Caracas: CAF-Development Bank of Latin America.

Campos-Vazquez, R. E. Chavez and G. Esquivel. 2016. "Estimating Top Income Shares without Tax Return Data: Mexico since the 1990s." Serie documentos de trabajo del Centro de Estudios Económicos 2016-04. El Colegio de México.

Cimoli, M. and S. Rovira. 2008. "Elites and Structural Inertia in Latin America: An Introductory Note on the Political Economy of Development." Journal of Economic Issues, 42(2): 327-347.

Clifton, J. D. Díaz Fuentes and J. Revuelta. 2016. "Fiscal Policy and Inequality in Latin America, 1960-2012" in Bértola, L. and J. Williamson (eds.).

Clifton, J., D. Díaz-Fuentes and J. Revuelta. 2019. "Falling Inequality in Latin America: The Role of Fiscal Policy." Unpublished manuscript. University of Cantabria.

Corden, W.M. 1984. "Booming Sector and Dutch Disease Economics: Survey and Consolidation." Oxford Economic Papers, 36(3): 359-380.

Cornia, A, J. Gómez-Sabaini, and B. Martorano. 2011. "A New Fiscal Pact, Tax Policy Changes and Income Inequality.” WIDER Working Paper 2011/70. Helsinki: UNU-WIDER.

Cornia, G., J.C. Gómez-Sabaini and B. Martorano. 2014. "Tax Policy and Income Distribution During the Last Decade" in Cornia, G.A (ed).

Cornia, G.A. 2010. "Income Distribution under Latin America's New Left Regimes." Journal of Human Development and Capabilities, 11(1): 85-114.

Cornia, G.A, ed. 2014. Falling Inequality in Latin America: Policy Change and Lessons, Oxford: Oxford University Press for UN-WIDER.

ECLAC. 2012. Statistical Yearbook of Latin America and the Caribbean 2012. Santiago: Economic Commission of Latin America and the Caribbean.

ECLAC. 2014. Statistical Yearbook of Latin America and the Caribbean 2014. Santiago: Economic Commission of Latin America and the Caribbean.

Fairfield, T. and M. Jorratt. 2016. "Top Income Shares, Business Profits and Effective Taxes in Contemporary Chile." Review of Income and Wealth, 62: S120-S144.

Fajnzylber, F. 1990. Industrialization in Latin America: From the "Black Box" to the "Empty Box." Santiago, Chile: Cuadernos de la CEPAL.

Gasparini, L. G. Cruces, L. Tornarolli and D. Mejía. 2011. "Recent Trends in Income Inequality in Latin America.” Economía, 11(2): 147-201.

Gasparini, L., G. Cruces and L. Tornarolli. 2016. "Chronicle of a Deceleration Foretold: Income Inequality in Latin America in the 2010s." Revista de Economía Mundial, 43: 25-45. 
Gasparini, L., S. Galiani, G. Cruces and P. Acosta. 2011. "Educational Upgrading and Returns to Skills in Latin America: Evidence from a Supply-Demand Framework, 1990-2010.” IZA Discussion Paper No 6244.

Goderis, B. and S. Malone. 2011. "Natural Resource Booms and Inequality: Theory and Evidence." Scandinavian Journal of Economics, 113 (6): 388-417.

Goñi, E., J. López, and L. Servén. 2008. "Fiscal Redistribution and Income Inequality in Latin America." Policy Research Working Paper; No. 4487. World Bank, Washington, DC.

Huber, E. and J. Stephens. 2012. Democracy and the Left: Social Policy and Inequality in Latin America. Chicago, IL: University of Chicago Press.

Huber, E., T. Mustillo, and J. Stephens. 2008. "Politics and Social Spending in Latin America." The Journal of Politics, 70(2): 420-36.

Johannsen, J., L. Tejerina and A. Glassman. 2009. Conditional Cash Transfers in Latin America: Problems and Opportunities. Washington DC: Inter-American Development Bank.

Keifman, S. and R. Maurizio. 2012. "Changes in Labour Market Conditions and Policies: Their Impact on Wage Inequality during the Last Decade." WIDER Working Paper 2012/14.

Lakner, C. and B. Milanovic. 2013. "Global Income Distribution. From the Fall of the Berlin Wall to the Great Recession." World Bank Policy Research Working Paper 6719.

Leamer, E., H. Maul, S. Rodriguez and P. Schott. 1999. "Does Natural Resource Abundance Increase Latin American Income Inequality? Journal of Development Economics, 59: 3-42.

Levy, S. and N. Schady. 2013. "Latin America's Social Policy Challenge: Education, Social Insurance, Redistribution.” Journal of Economic Perspectives, 27(2): 193-218.

López Calva, L. and N. Lustig (eds). 2010. Declining Inequality in Latin America. A Decade of Progress? Washington, DC: Brookings Institution.

Lustig, N. 2012. "A Matter of Transparency: The Top One Percent in the Americas." Americas Quarterly, Spring at http://www.americasquarterly.org/lustig

Lustig, N. 2017. "El impacto del sistema tributario y el gasto social en la distribución del ingreso y la pobreza en América Latina. Una aplicación del marco metodológico del Proyecto Compromiso con la Equidad (CEQ)." Trimestre Económico, 84(3): 493568

Lustig, N. G. Gray-Molina, S. Higgins, M. Jaramillo, W. Jiménez, V. Paz, C. Pereira, Carola Pessino, J. Scott and E. Yañez. 2012. "The Impact of Taxes and Social Spending on Inequality and Poverty in Argentina, Bolivia, Brazil, Mexico and Peru: A Synthesis of Results." CEQ Working Paper No. 3.

Lustig, N., L.F. Lopez-Calva and E. Ortiz-Juarez. 2016. "Deconstructing the Decline in Inequality in Latin America." In Inequality and Growth: Patterns and Policy: Volume II: Regions and Regularities edited by Basu, K. and J. Stiglitz. London: Palgrave MacMillan (and World Bank).

Mahon, J. Forthcoming. "Taxation, State Capacity and Redistribution in Latin America." In The Oxford International Handbook of Governance and Management 
for Social Policy edited by Arza, C., M. Blomfield and F. Filgueira Oxford: Oxford University Press.

Martínez Franzoni, J. and D. Sánchez-Ancochea. 2014. "The Double Challenge of Market and Social Incorporation: Progress and Bottlenecks in Latin America." Development Policy Review, 32(3): 275-298.

Martínez Franzoni, J. and D. Sánchez-Ancochea. 2016. "Regímenes del bienestar en América Latina: tensiones entre universalización y segmentación." In Los Estados del Bienestar en la encrucijada: Polítias sociales en perspectiva comparada edited by Del Pino, E. and M.J. Rubio Lara. Madrid: Tecnos.

Martínez Franzoni, J. and D. Sánchez-Ancochea. 2018. "Undoing Segmentation? Latin American Health Care Policy During the Economic Boom." Social Policy \& Administration, 52(6): 1181-1200.

Maurizio, R. 2014. "Labour Formalization and Declining Inequality in Argentina and Brazil in the 2000s: A Dynamic Approach." ILO Research Paper No. 9.

Maurizio, R. and G. Vázquez. 2016. "Distribution effects of the minimum wage in four Latin American countries: Argentina, Brazil, Chile and Uruguay." International Labour Review, 155(1): 97-131.

Medeiros, M., P. Ferreira de Souza, and F. Avila de Castro. 2015. "O topo da distribuição de renda no Brasil: Primeiras estimativas com dados tributários e comparação com pesquisas domiciliares (2006-2012)." DADOS. Revista de Ciencias Sociais, 58(1): 7-36.

Moreno-Brid, J.A., S. Garry and A. Krozer. 2016. "Minimum Wages: An Embarrassing Inequality in Mexico from a Comparative Perspective with Latin America." Revista de Economía Mundial, 43: 113-129.

Morgan, M. 2017. "Extreme and Persistent Inequality: New Evidence for Brazil Combining National Accounts, Surveys and Fiscal Data, 2001-2015." WID Working Paper Series, no 2017/12.

Murillo, V., L. Ronconi and A. Schrank. 2011. "Latin American Labor Reforms: Evaluating Risk and Security," In The Oxford Handbook of Latin American Economics edited by Ocampo, J.A. and J. Ros. Oxford: Oxford University Press.

Ocampo, J.A. 2017. "Commodity-Led Development in Latin America." In Alternative Pathways to Sustainable Development: Lessons from Latin America. International Development Policy series No.9, Geneva: Graduate Institute Publications at https://journals.openedition.org/poldev/2354.

Ocampo, J. A. and M. Parra. 2010. "The Terms of Trade for Commodities since the Mid-Nineteenth Century." Revista de Historia Económica - Journal of Iberian and Latin American Economic History, 28(1): 11-37

OECD/ECLAC/CIAT/IDB. 2013. Revenue Statistics in Latin America and the Caribbean 2013. OECD Publishing, Paris.

OECD/ECLAC/CIAT/IDB. 2015. Revenue Statistics in Latin America and the Caribbean 2015. OECD Publishing, Paris.

OECD/ECLAC/CIAT/IDB. 2016. Revenue Statistics in Latin America and the Caribbean 2016. OECD Publishing, Paris. 
Prados de la Escosura, L. 2007. "Inequality and Poverty in Latin America: A LongRun Exploration." In The New Comparative Economic History: Essays in Honor of Jeffrey G. Williamson edited by Hatton, T. K. O'Rourke and A. Taylor. Cambridge, MA: MIT Press.

Prebisch, R. 1976. "A Critique of Peripheral Capitalism." CEPAL Review, 1: 9-76.

Reygadas, L. and F. Filgueira. 2010. "Inequality and the Incorporation Crisis: The Left's Social Policy Toolkit." In Latin America's Left Turns. Politics, Policies and Trajectories of Change edited by Cameron, M. and E. Hershberg. Boulder, CO and London: Lynn Rienner.

Ronconi, L. 2012. "Globalization, Domestic Institutions, and Enforcement of Labor Law: Evidence from Latin America." Industrial Relations, 51(1): 89-105.

Sojo, A. 2017. Protección social en América Latina: la desigualdad en el banquillo. Santiago: Economic Commission for Latin America and the Caribbean.

Stampini, M. and L. Tornarolli. 2012. "The Growth of Conditional Cash Transfers in Latin America and the Caribbean: Did They Go Too Far?" IZA Policy Paper No. 49.

Székely, M. and M. Hilgert. 2007. "What's Behind the Inequality We Measure? An Investigation Using Latin American Data." Oxford Development Studies, 35(2): 197 217.

Vargas, M. and S. Garriga. 2015. "Explaining Inequality and Poverty Reduction in Bolivia." IMF Working Paper 15/265.

Weller, J. 2014. “Aspectos de la evolución reciente de los mercados laborales de América Latina y el Caribe.” Revista de la CEPAL, 114: 7-29.

Weller, J. and C. Roethlisberger. 2011. "La calidad del empleo en América Latina." serie Macroeconomía del Desarrollo, $N^{\circ} 110$ Santiago de Chile: Economic Commission for Latin America and the Caribbean.

Williamson, J. (2009) "Five Centuries of Latin American Inequality." NBER Working Papers no 15305.

World Bank. 2004. Inequality in Latin America. Breaking with History? Washington, DC: World Bank.

World Bank. 2013. "One in Every Four Latin Americans is Covered by Programs such as the Bolsa Família and Oportunidades.” Digital Feature Story, World Bank Group at http://www.worldbank.org/en/news/feature/2013/07/15/Brazil-LatinAmerica-covered-social-safety-nets (last accessed November 6, 2018).

World Bank. 2015. Working to End Poverty in Latin America and the Caribbean Workers, Jobs, and Wages. Washington, DC: World Bank Group. 
Figure 1. Changes in the Gini coefficient, annual average per year, circa 2000s-circa 2012

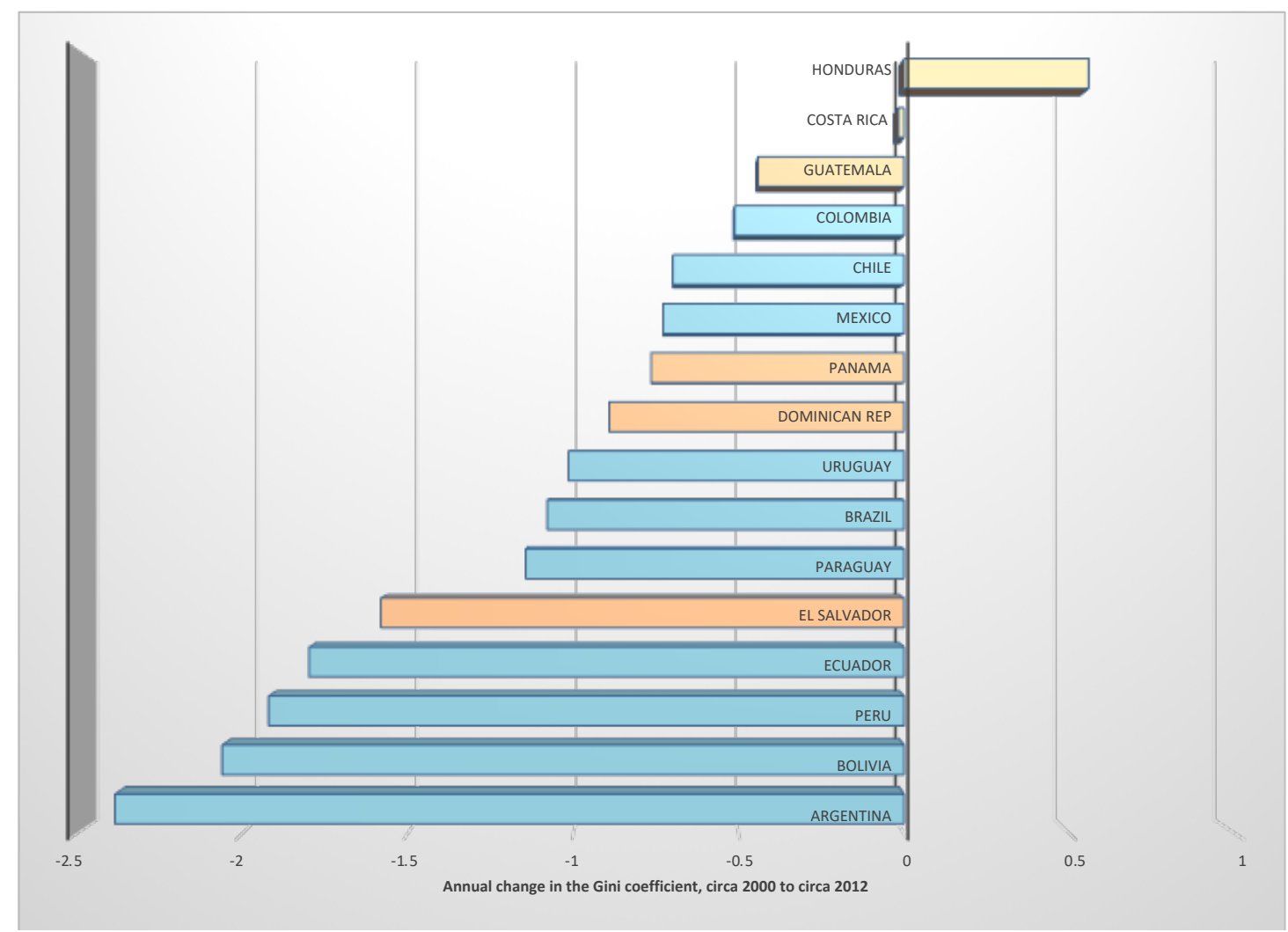

Source: own calculations with data from SCEDLAS

NOTE: countries that benefited from the commodity boom appear in light blue 
Figure 2. Percentage change in the income share of the top decile, 2001-2012

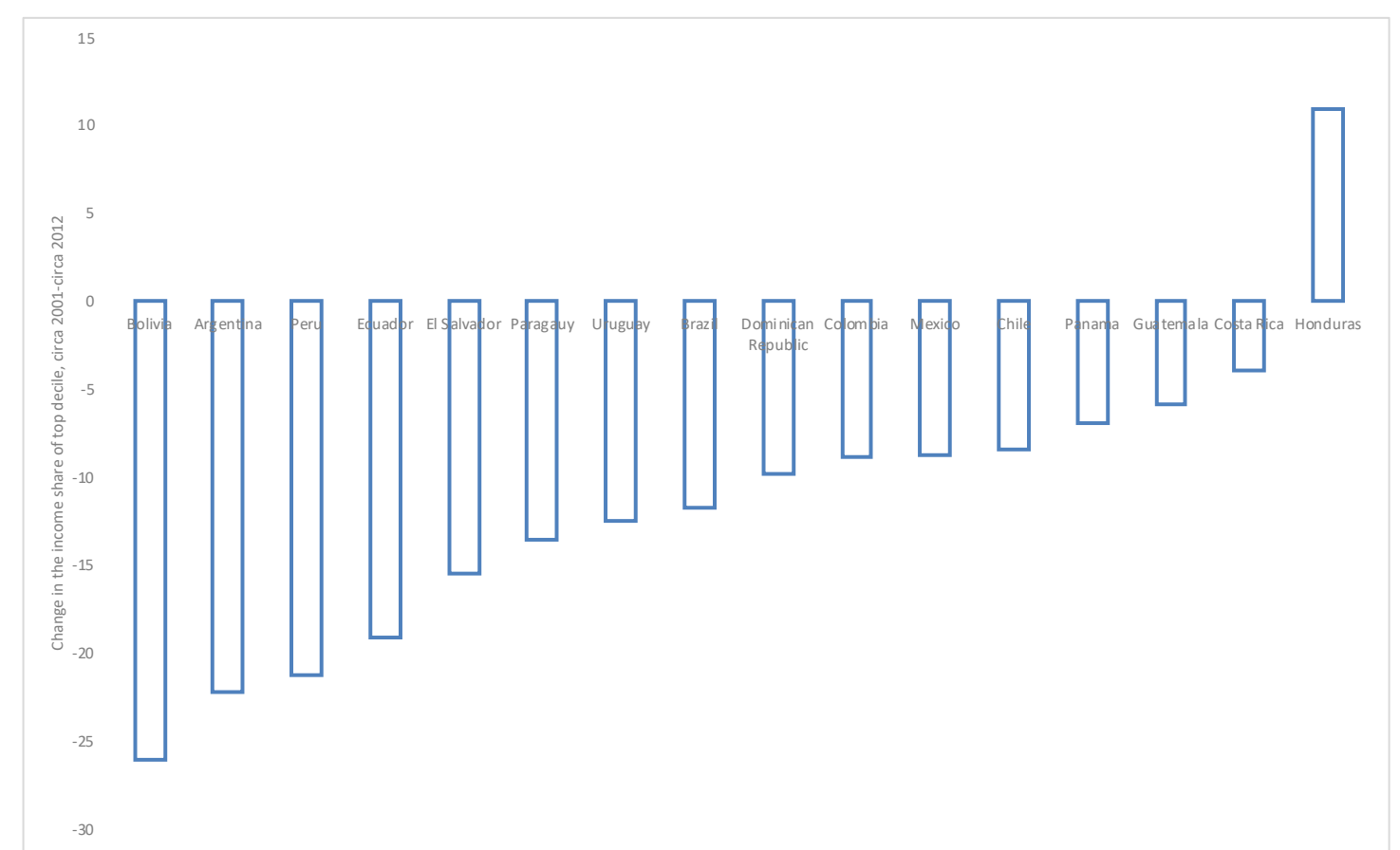

Source: own calculations with data from SCEDLAS 
Table 1. Income share of the top 1 percent in several Latin American countries (\% of pre-tax income)

\begin{tabular}{|l|c|c|c|c|c|c|c|c|}
\hline & Argentina & \multicolumn{2}{|c|}{ Brazil } & \multicolumn{2}{c|}{ Chile } & Colombia & Mexico & Uruguay \\
\hline & & 1 & 2 & 1 & 2 & & & \\
\hline 1997 & 12 & & & & & 21 & & \\
\hline 2000 & 14 & & & & & 17 & 27 & \\
\hline 2001 & 13 & & 26 & & 20 & 17 & & \\
\hline 2002 & 15 & & 27 & & 20 & 18 & & \\
\hline 2003 & 17 & & 27 & & 19 & 20 & & \\
\hline 2004 & 17 & & 27 & & 22 & 18 & 25 & \\
\hline 2005 & & & 28 & $22-32$ & 22 & 19 & & \\
\hline 2006 & & 23 & 28 & $21-31$ & 23 & 20 & 27 & \\
\hline 2007 & & 24 & 28 & $21-31$ & 25 & 21 & & \\
\hline 2008 & & 26 & 29 & $24-36$ & 21 & 20 & 27.5 & \\
\hline 2009 & & 25 & 27 & $22-33$ & 24 & 20 & & 14 \\
\hline 2010 & & 25 & 28 & $20-30$ & 26 & 20 & 26 & 14 \\
\hline 2011 & & 27 & 30 & $20-30$ & 24 & & & 14 \\
\hline 2012 & & 26 & 28 & $20-30$ & 23 & & 27 & \\
\hline 2013 & & & 28 & & 22 & & & \\
\hline 2014 & & & 28 & & 23 & & 30 & \\
\hline 2015 & & & 28 & & 24 & & & \\
\hline
\end{tabular}

Source: Alvarado (2010); Alvarado and Londoño (2013); Budin et al. (2014); and Campos-Vazquez et al (2016). For Brazil, (1) Medeiros et al (2015) and (2) is Morgan (2017) as reflected in the World Inequality Database (WID). For Chile, (1) is Fairfield and Jorratt (2016) and (2) is Atria et al (2018) as reflected in the WID. 
Figure 3. Total increase in the years of education of the labour force in Latin America, 1990s and 2000s

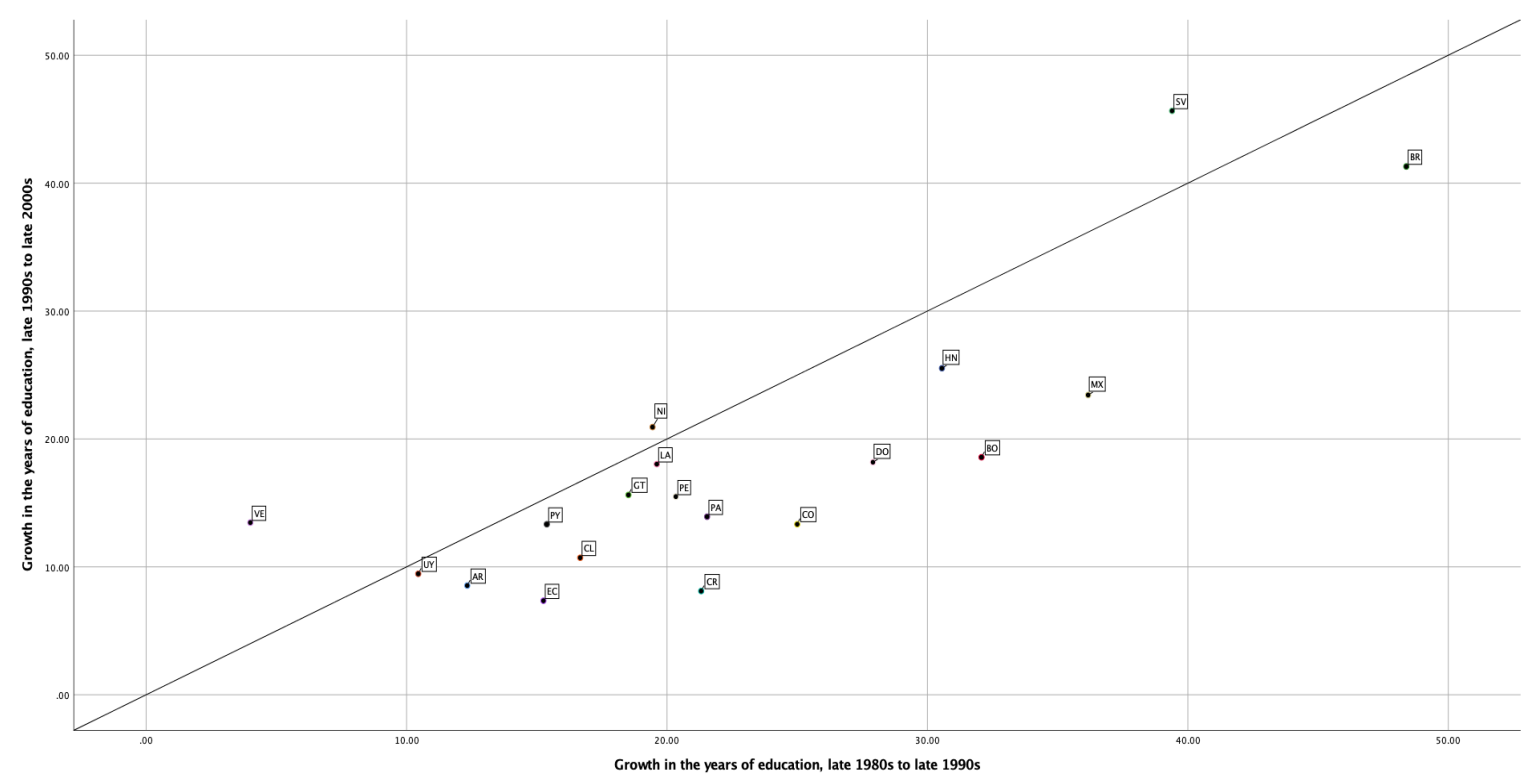

Source: own elaboration with data from Szekely and Mendoza (2017) 
Figure 4. Share of services in total employment in Latin America, 2002 and 2013

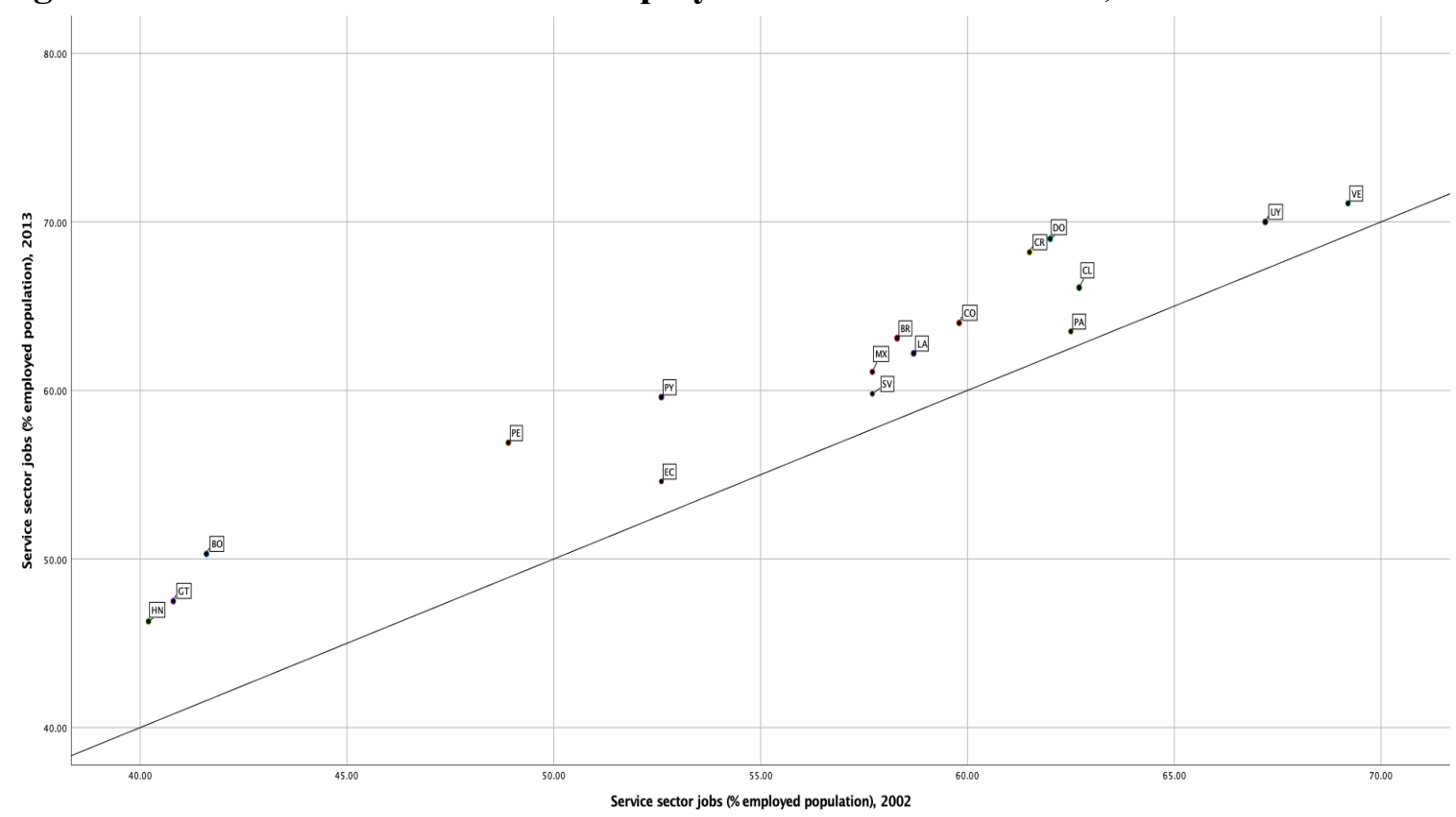

Source: own calculation with ECLAC data 
Figure 5. Unemployment rate of all workers and for workers with primary education or less, 2000-2013

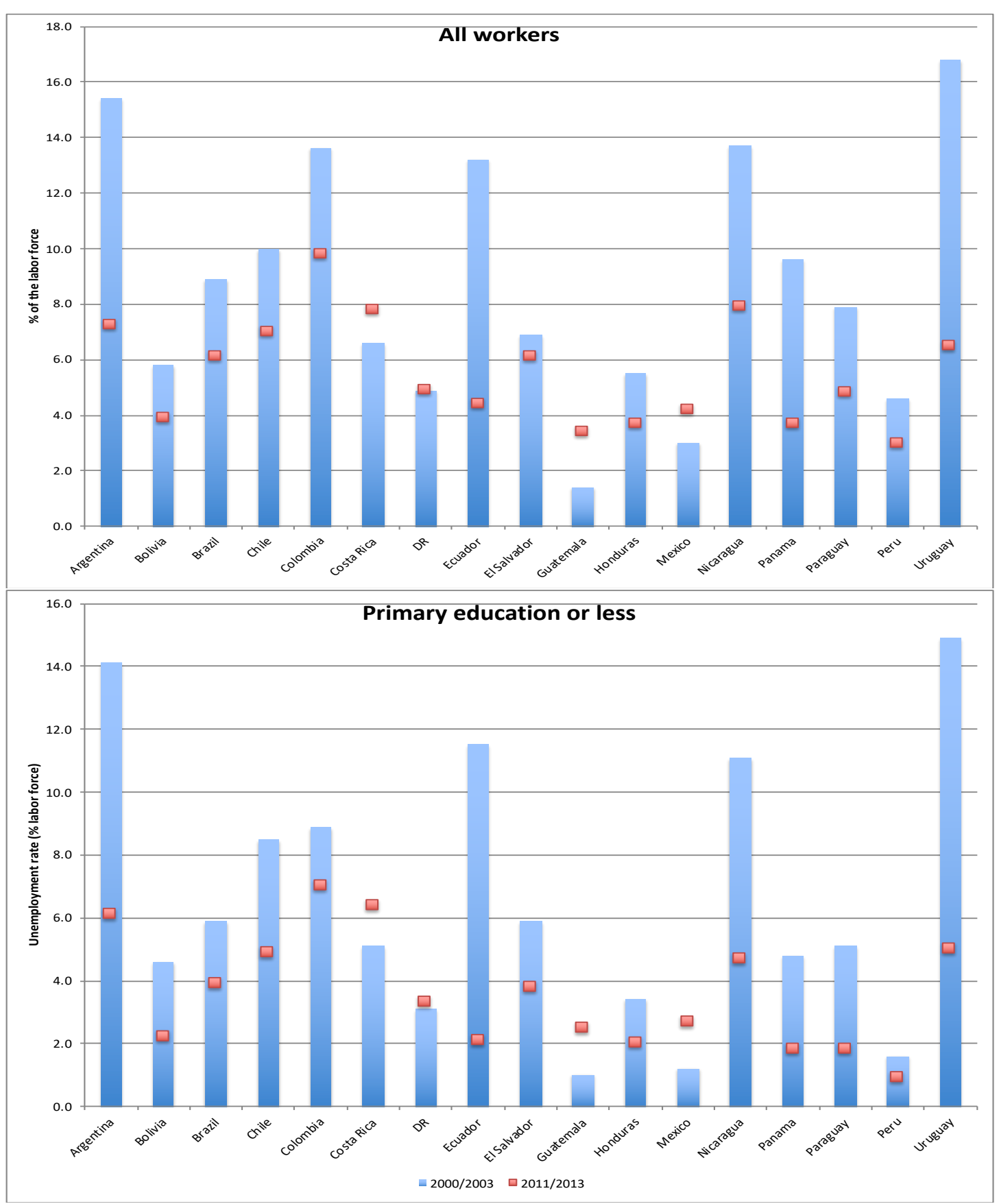

Source: own elaboration with SCEDLAS data 
Figure 6. Average and minimum wages, index numbers, 2013 (2000=100)

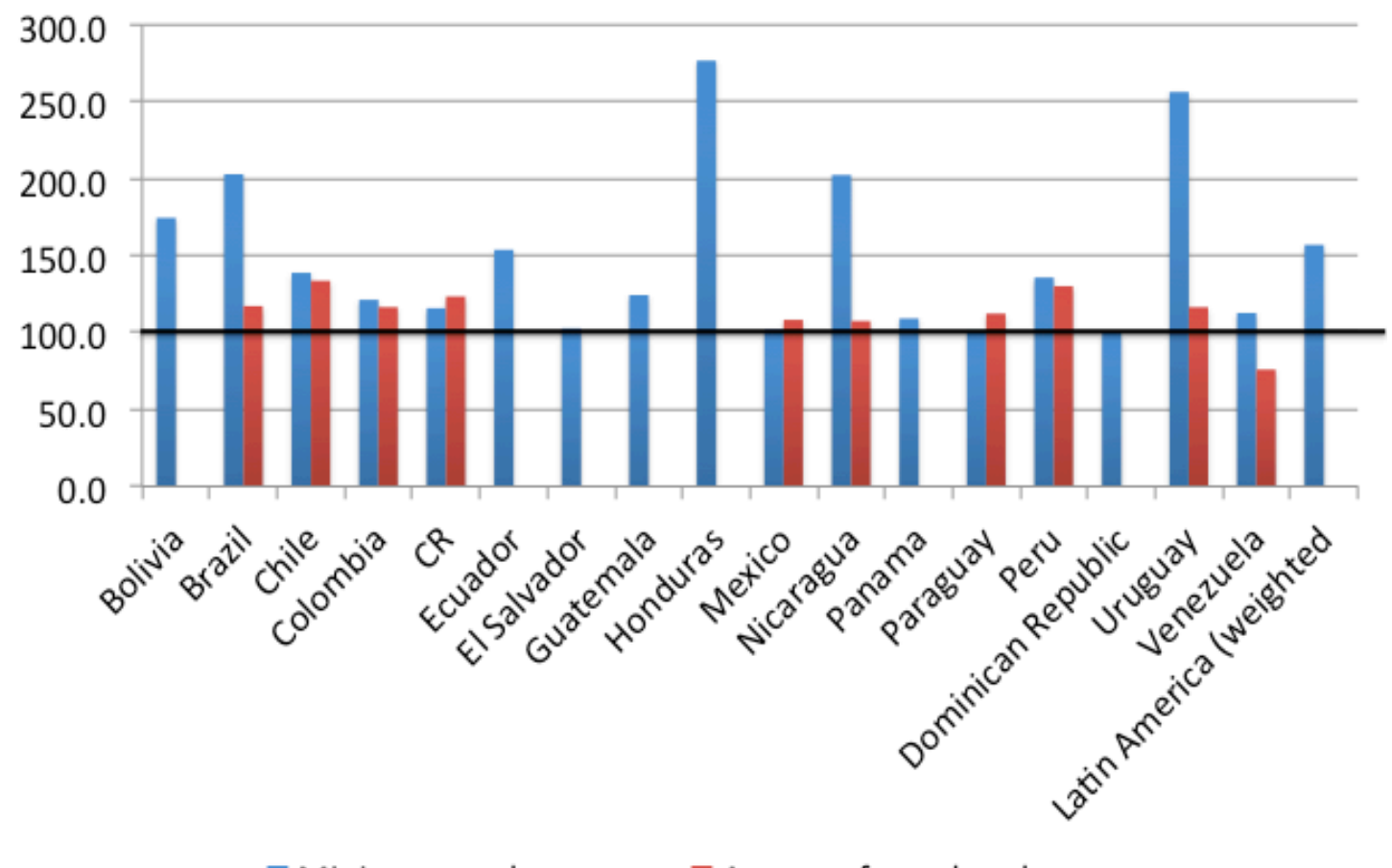

Minimum real wages $\quad$ Average formal real wages

Source: own elaboration with ILO data 
Figure 7. Comparison of the tax revenue increase in the 1990s and 2000s, percentage points

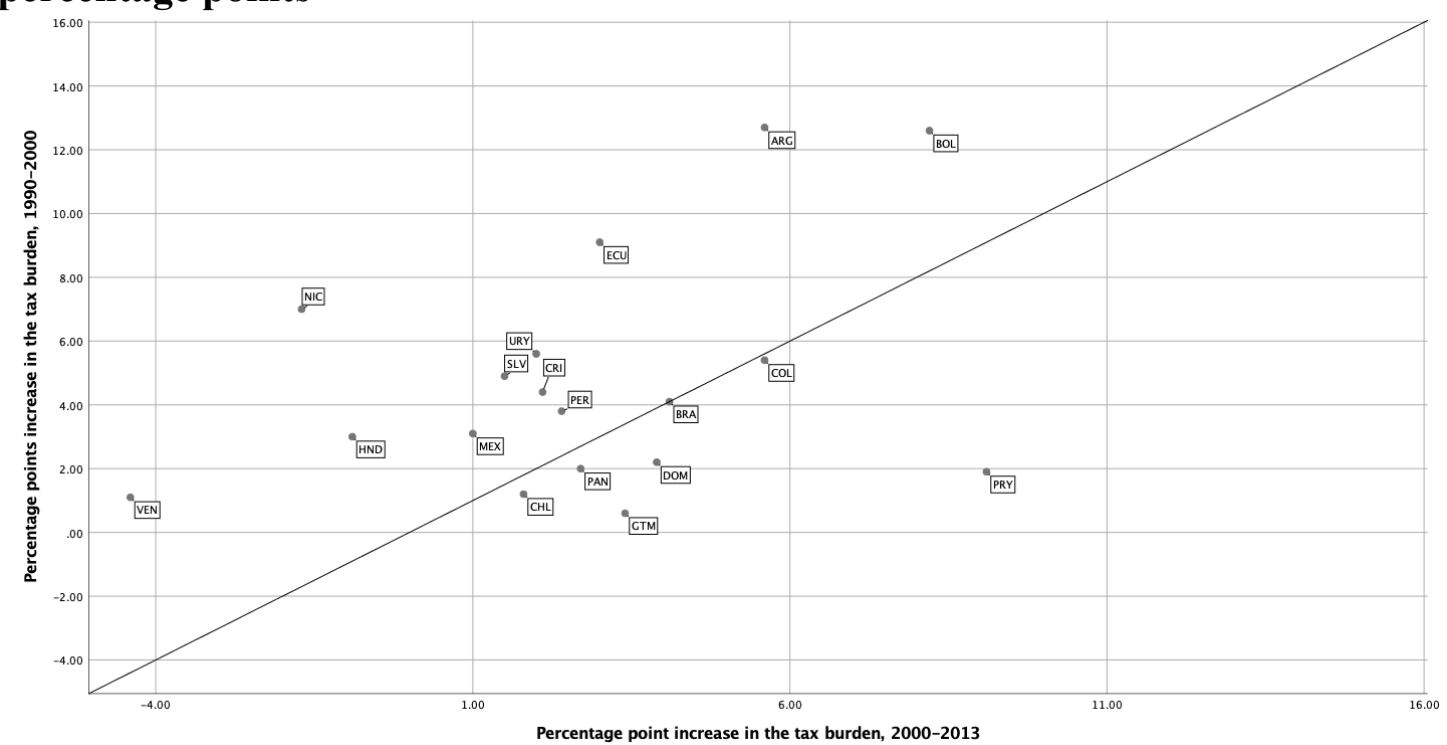

Source: own elaboration with data from OECD et al (2016)

NOTE: the graph is comparing the change in the share of taxes as percentage of GDP in 1990-2000 and in $2000-2013$ 
Table 2. Degree of progressivity (ratio between income and general consumption taxes), 1990, 2000 and 2013

\begin{tabular}{|c|c|c|c|c|}
\hline & 1990 & 2000 & 2013 & $\begin{array}{l}\text { Progresivity increases more } \\
\text { in } 2000 \mathrm{~s} \text { than } 1990 \mathrm{~s}\end{array}$ \\
\hline \begin{tabular}{|l|} 
Argentina \\
\end{tabular} & 15.7 & 46.1 & 49.4 & $\mathrm{~N}$ \\
\hline Bolivia & 24.8 & 36.5 & 49.9 & $\mathrm{Y}$ \\
\hline Brazil & 38.2 & 44.6 & 52.9 & $\mathrm{Y}$ \\
\hline Chile & 62.2 & 55.7 & 85.2 & $\mathrm{Y}$ \\
\hline Colombia & 114.7 & 74.1 & 118.0 & $\mathrm{Y}$ \\
\hline Costa Rica & 55.4 & 57.8 & 86.2 & $\mathrm{Y}$ \\
\hline Dominican Republic & 171.8 & 105.8 & 95.5 & $\mathrm{Y}$ \\
\hline Ecuador & 45.5 & 35.1 & 63.5 & $\mathrm{Y}$ \\
\hline El Salvador & 72.0 & 57.0 & 85.5 & $\mathrm{Y}$ \\
\hline Guatemala & 66.5 & 52.6 & 73.3 & $\mathrm{Y}$ \\
\hline Honduras & 125.3 & 58.0 & 95.0 & $\mathrm{Y}$ \\
\hline Mexico & 130.2 & 145.9 & 171.9 & $\mathrm{Y}$ \\
\hline Nicaragua & -- & 39.0 & 86.8 & -- \\
\hline Panama & 270.0 & 702.5 & 173.3 & $\mathrm{~N}$ \\
\hline Paraguay & -- & 40.9 & 39.5 & -- \\
\hline Peru & 47.7 & 53.9 & 106.7 & $\mathrm{Y}$ \\
\hline Uruguay & 17.2 & 31.2 & 72.8 & $\mathrm{Y}$ \\
\hline Venezuela & -- & 143.2 & 56.9 & -- \\
\hline
\end{tabular}

Source: own elaboration with data from OECD et al (2016)

NOTE: the average includes 22 countries from Latin America and the Caribbean. The numbers reflect the relationship between the share of income taxes in GDP and the share of general consumption taxes in GDP. 
Figure 8. Public revenues from non-renewable resources and from other sources in selected countries, 2003 and 2012

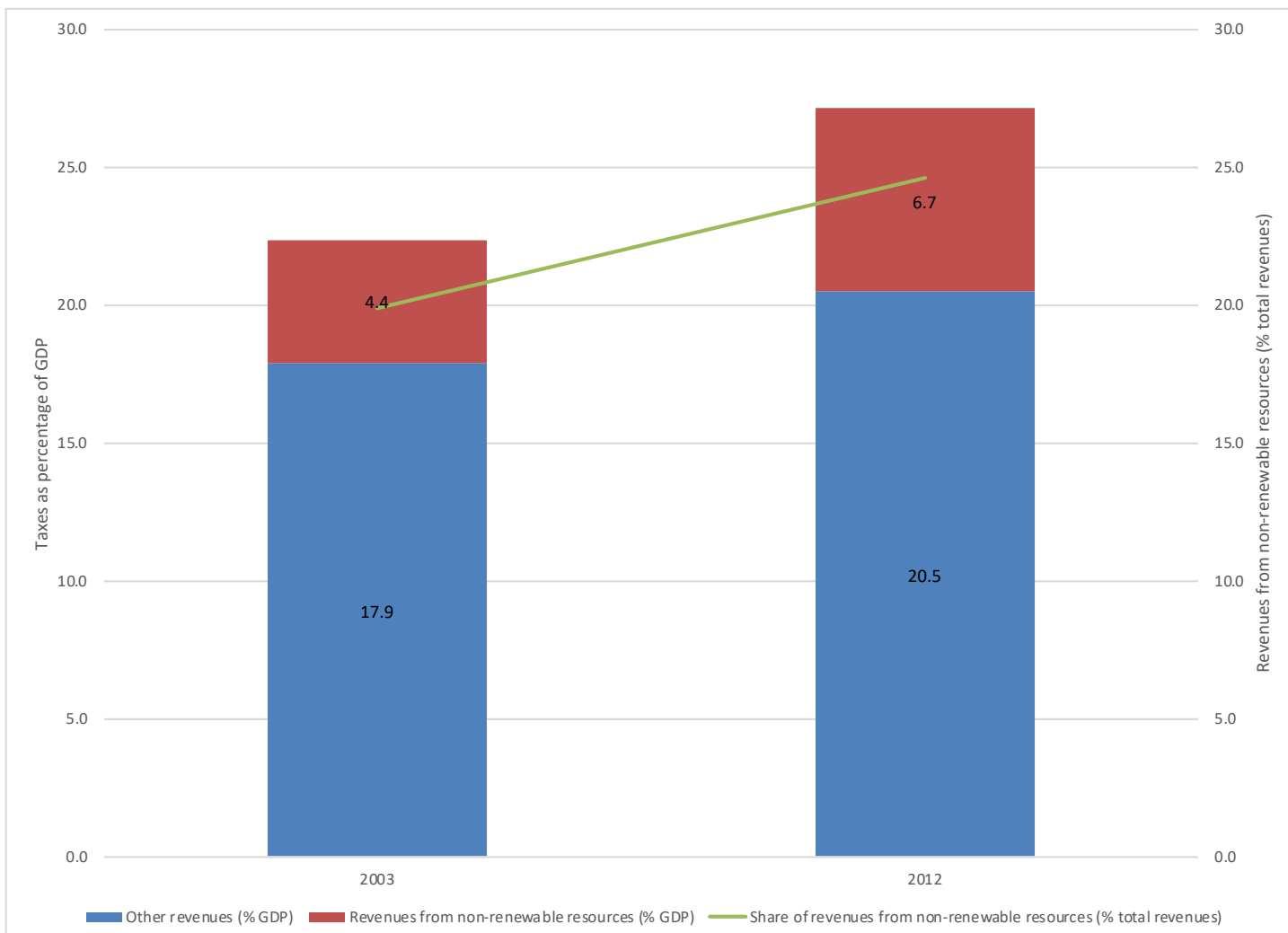

Source: own elaboration with data from OECD et al (2013)

NOTE: the countries included are Argentina, Bolivia, Brazil, Colombia, Ecuador, Mexico, Peru and Venezuela. Non-renewable resources include minerals, metals and hydrocarbons 
Figure 9. Public social spending of the central government in Latin America (\% GDP and per capita), 2000-2013

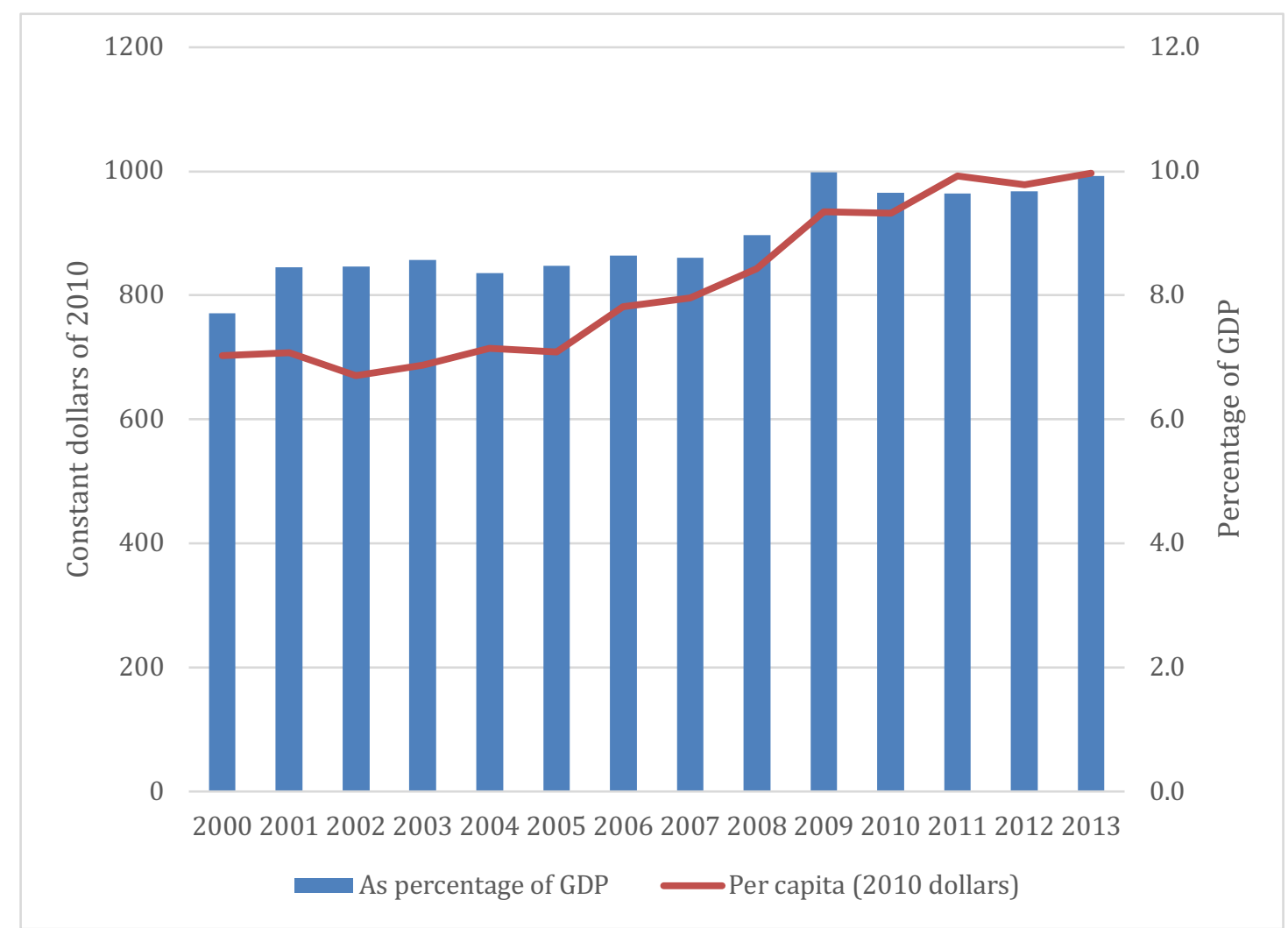

Source: own elaboration with ECLAC data 
Figure 10. Public social spending by the central government per sub-sector $(\%$ GDP), 2003 and 2013

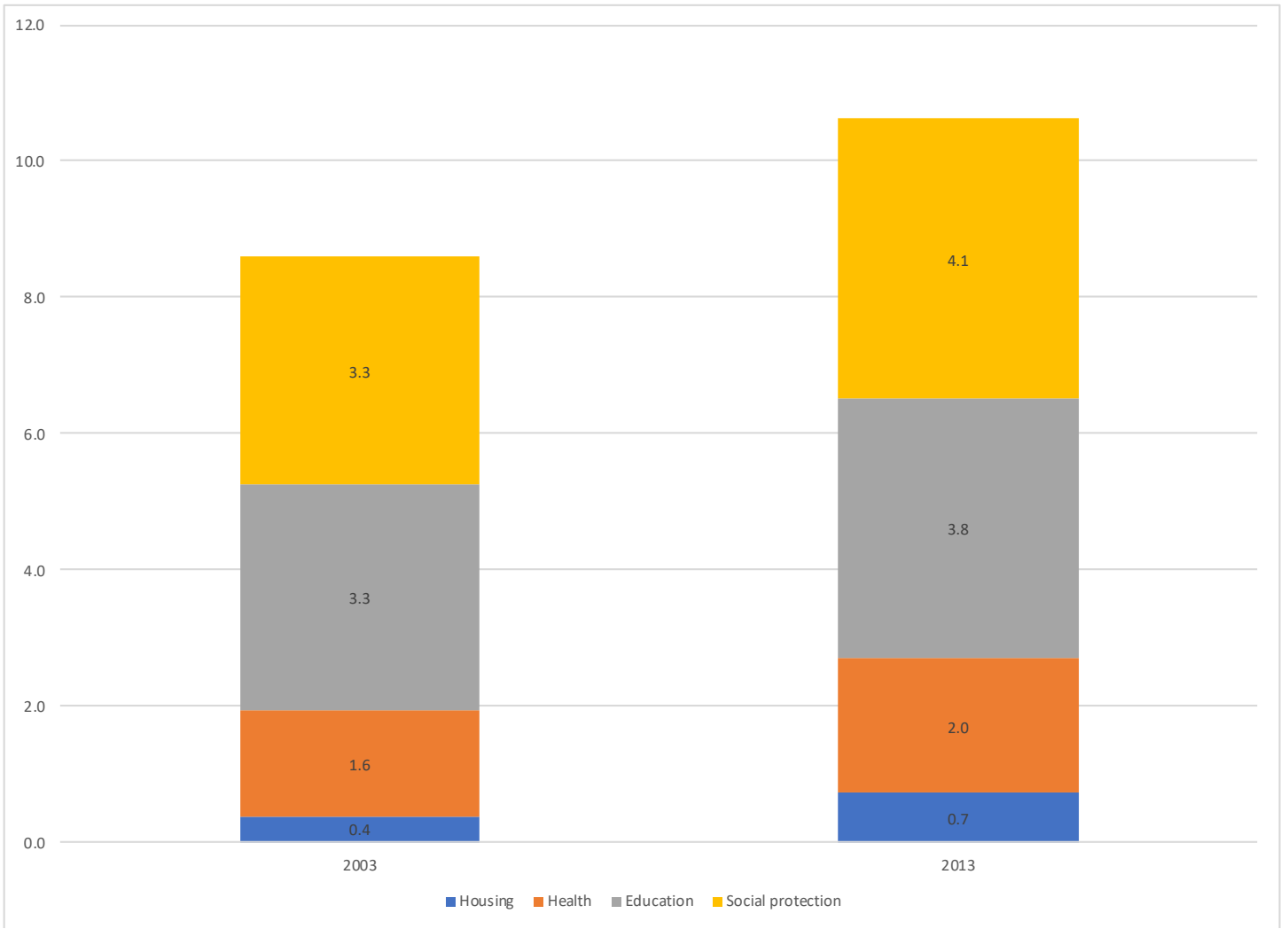

Source: own elaboration with ECLAC data 
Table 3. Working population with social insurance (health care or pensions), 2000, 2005 and 2012

\begin{tabular}{|l|l|c|c|c|l|}
\hline Years & Total & \multicolumn{2}{|l|}{ Salaried workers } & Self-employed & $\begin{array}{l}\text { Domestic } \\
\text { workers }\end{array}$ \\
\hline & & Total & $\begin{array}{l}\text { Business w/ } \\
5 \text { workers }\end{array}$ & & \\
\hline 2000 & 55.0 & 71.8 & 32.9 & 24.5 & 27.3 \\
\hline 2005 & 54.5 & 71.9 & 32.9 & 21.7 & 30.8 \\
\hline 2012 & 64.0 & 82.3 & 50.1 & 32.9 & 36.3 \\
\hline
\end{tabular}

Source: ILO (various years) 
Table 4. Health care coverage in 2000 compared to 2013

\begin{tabular}{|c|c|c|c|c|c|}
\hline & $\begin{array}{c}\text { Health insurance (\% } \\
\text { salaried workers) }\end{array}$ & $\begin{array}{l}\text { Health insurance }(\% \\
\text { non-salaried workers) }\end{array}$ & $\begin{array}{c}\text { Health insurance (\% } \\
\text { salaried workers), } \\
\text { Q1vsQ5 }\end{array}$ & $\begin{array}{c}\text { Health insurance (\% } \\
\text { non-salaried workers), } \\
\text { Q1vsQ5 }\end{array}$ & $\begin{array}{c}\text { Health insurance (\% } \\
\text { salaried workers), } \\
\text { domestic service vs } \\
\text { public sector }\end{array}$ \\
\hline \multicolumn{6}{|c|}{ Countries benefiting from the commodity boom } \\
\hline Argentina & 12.7 & 9.0 & 22.7 & 8.1 & 3.9 \\
\hline Bolivia & 15.6 & 11.5 & 17.1 & 45.1 & 14.5 \\
\hline Chile & 3.9 & 13.1 & 5.2 & -4.8 & 5.5 \\
\hline Colombia & 39.6 & 74.1 & 67.4 & 82.4 & 63.2 \\
\hline Ecuador & 21.0 & 9.6 & 8.4 & 7.8 & 27.9 \\
\hline Mexico & 23.2 & 69.3 & 67.7 & 105.8 & 65.8 \\
\hline Paraguay & 12.4 & 5.8 & 9.1 & 3.6 & 12.9 \\
\hline Peru & 28.6 & 43.0 & 63.6 & 134.3 & 43.3 \\
\hline Uruguay & 0.9 & 0.9 & -0.9 & -1.9 & -0.3 \\
\hline Average & 17.5 & 26.3 & 28.9 & 42.3 & 26.3 \\
\hline Standard deviation & 12.1 & 28.4 & 28.8 & 52.6 & 25.4 \\
\hline \multicolumn{6}{|c|}{ Countries not benefiting from the commodity boom } \\
\hline Costa Rica & 4.1 & 12.4 & 3.0 & 1.0 & 6.3 \\
\hline El Salvador & 1.0 & 1.1 & 2.9 & -2.6 & 4.4 \\
\hline Guatemala & 6.7 & 4.5 & 0.9 & 7.1 & 5.6 \\
\hline Honduras & 1.2 & 0.1 & 0.5 & 4.9 & 1.5 \\
\hline Nicaragua & 7.5 & 0.0 & 0.5 & -1.9 & -1.2 \\
\hline Panama & -0.2 & 2.9 & -10.0 & 4.4 & 15.5 \\
\hline Average & 3.4 & 3.5 & -0.4 & 2.2 & 5.3 \\
\hline Standard deviation & 3.2 & 4.7 & 4.9 & 3.9 & 5.7 \\
\hline
\end{tabular}

NOTES: Data for Brazil and Venezuela is not available. The numbers reflect the value for 2013 minus the value for 2000. The classification of countries between those that benefited and those that did not benefit from the commodity boom is based on data from Ocampo (2017).

Source: own calculations with data from Martínez Franzoni and Sánchez-Ancochea (2018) 
Appendix 1. Percentile change in the income share per decile, 2001-2012

Source: own elaboration based on data from SCEDLAS

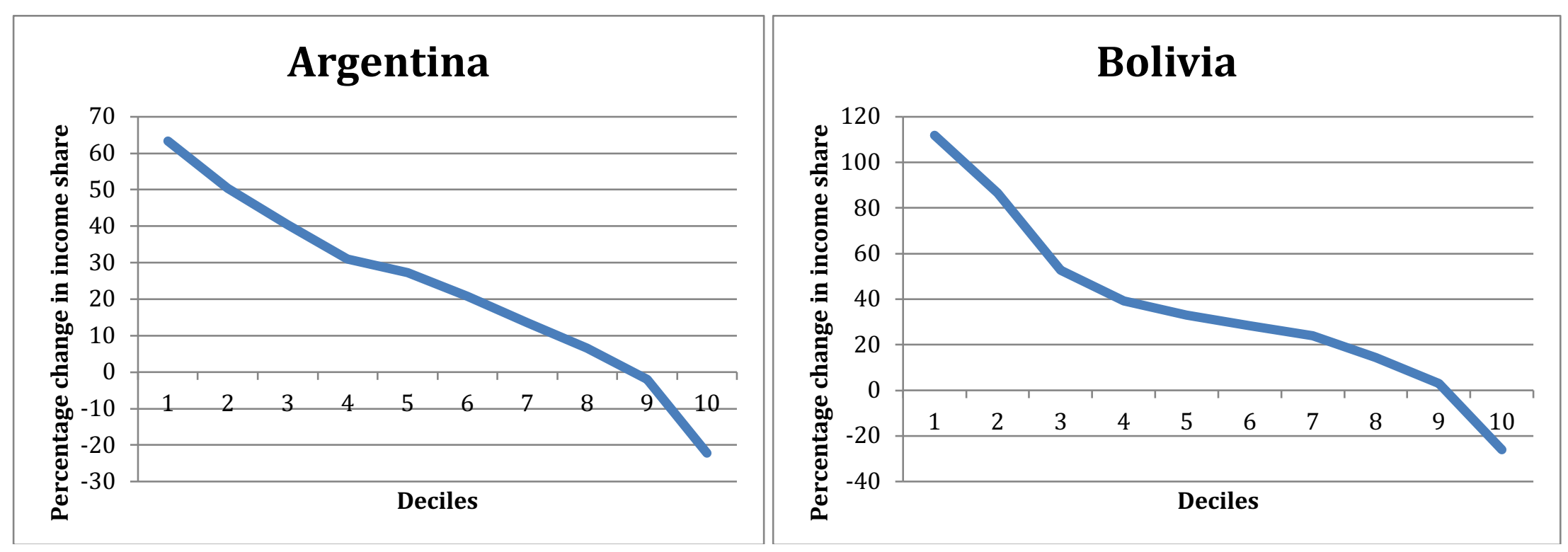



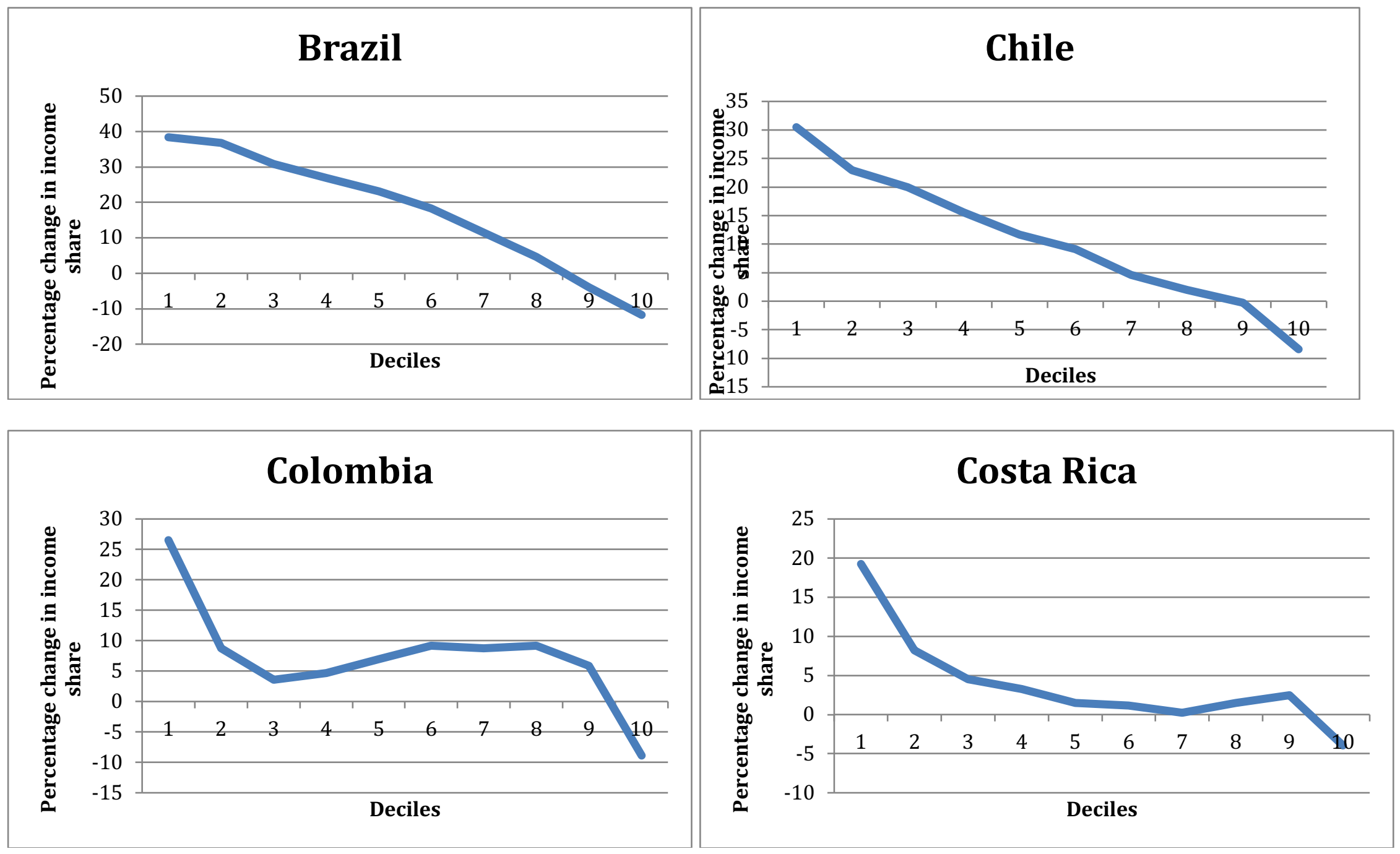

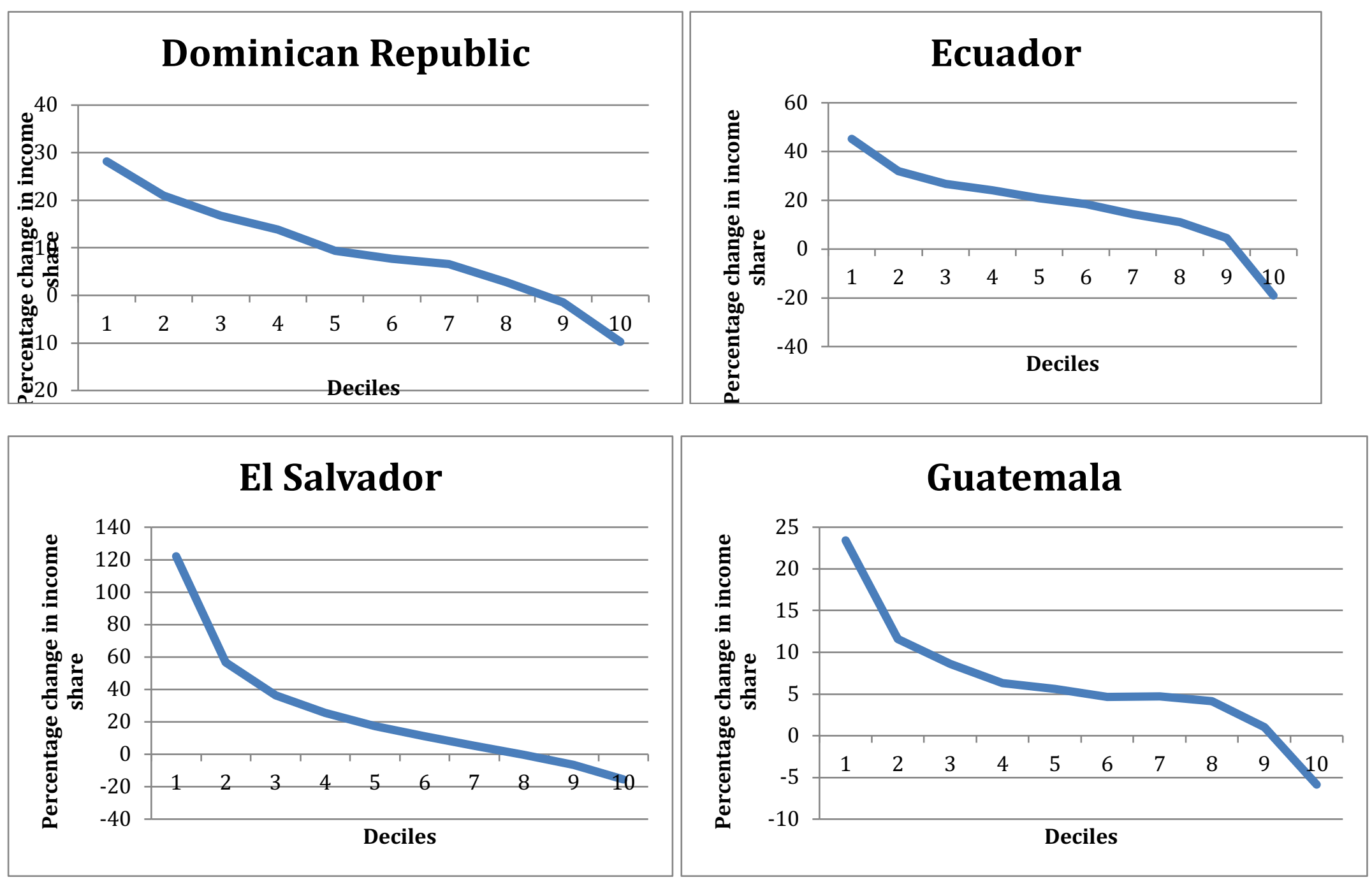

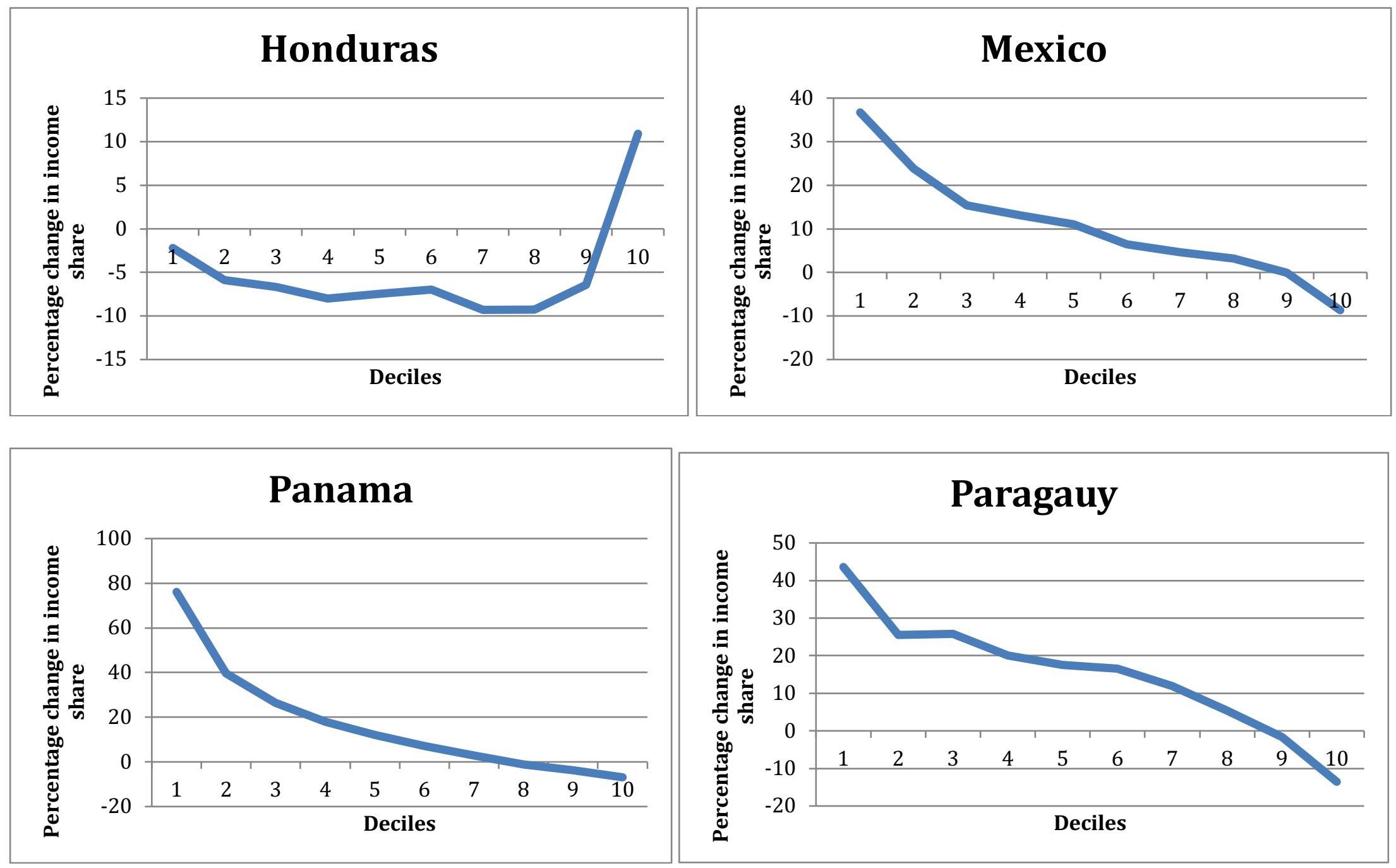

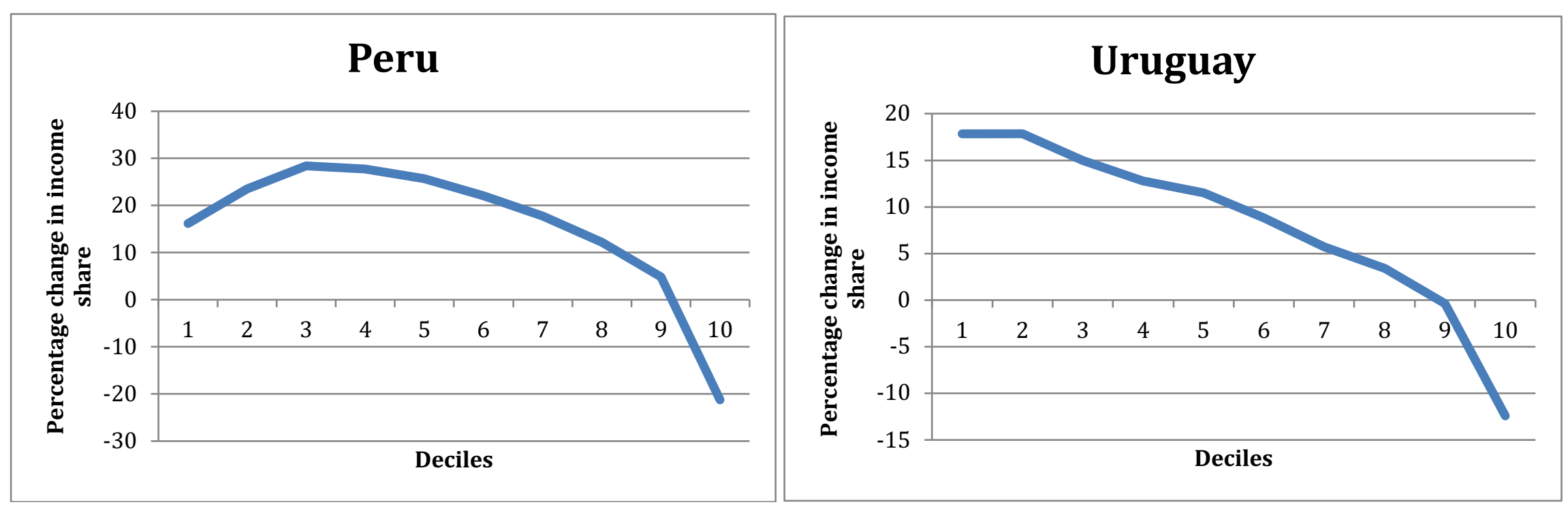
